\title{
Probiotic Effects against Virus Infections: New Weapons for an Old War
}

\author{
Aroa Lopez-Santamarina ${ }^{1}$, Alexandre Lamas ${ }^{1}{ }^{\mathbb{B}}$, Alicia del Carmen Mondragón ${ }^{1}$, Alejandra Cardelle-Cobas ${ }^{1}$,

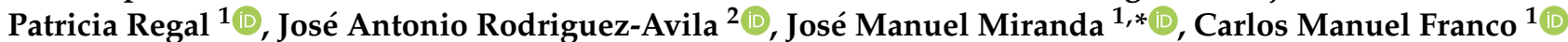 \\ and Alberto Cepeda ${ }^{1}$
}

1 Laboratorio de Higiene Inspección y Control de Alimentos, Departamento de Química Analítica, Nutrición y Bromatología, Universidad de Santiago de Compostela, 27002 Lugo, Spain; aroa.lopez.santamarina@usc.es (A.L.-S.); alexandre.lamas@usc.es (A.L.); aliciamondragon@yahoo.com (A.d.C.M.); alejandra.cardelle@usc.es (A.C.-C.); patricia.regal@usc.es (P.R.); carlos.franco@usc.es (C.M.F.); alberto.cepeda@usc.es (A.C)

2 Área Académica de Química, Instituto de Ciencias Básicas e Ingeniería, Universidad Autónoma del Estado de Hidalgo, Carretera Pachuca-Tulancingo Km. 4.5, Pachuca 42076, Hidalgo, Mexico; josear@uaeh.edu.mx

* Correspondence: josemanuel.miranda@usc.es

check for updates

Citation: Lopez-Santamarina, A.; Lamas, A.; del Carmen Mondragón, A.; Cardelle-Cobas, A.; Regal, P.; Rodriguez-Avila, J.A.; Miranda, J.M.; Franco, C.M.; Cepeda, A. Probiotic Effects against Virus Infections: New Weapons for an Old War. Foods 2021, 10, 130. https://doi.org/10.3390/ foods10010130

Received: 17 December 2020

Accepted: 7 January 2021

Published: 9 January 2021

Publisher's Note: MDPI stays neutral with regard to jurisdictional clai$\mathrm{ms}$ in published maps and institutional affiliations.

Copyright: (C) 2021 by the authors. Licensee MDPI, Basel, Switzerland. This article is an open access article distributed under the terms and conditions of the Creative Commons Attribution (CC BY) license (https:// creativecommons.org/licenses/by/ $4.0 /)$.

\begin{abstract}
This review aimed to gather the available literature investigating the effects of probiotics against the most common viral infections using in vitro trials in cell lines and in vivo clinical trials in both experimental animals and humans. Probiotics were employed to prevent and reduce symptoms of infections caused by common viruses, especially respiratory tract viruses, but also for viral digestive infections (such as rotavirus, coronavirus, or norovirus) and other viral infections (such as viruses that cause hepatitis, human papillomavirus, human immunodeficiency virus, and herpes simplex virus). Different probiotics have been studied to see their possible effect against the abovementioned viruses, among which different Lactobacillus species, Bifidobacterium, Clostridium, Enterococcus, and Streptococcus can be highlighted. In many cases, mixtures of various probiotic strains were used. Although the results obtained did not show similar results, in most cases, probiotic supplementation improved both barrier and biochemical immune responses, decreased susceptibility to viral infections, and enhanced the effects of concomitant vaccines. Works collected in this review show a beneficial effect of probiotics in the prevention and treatment of different viral infections. We found interesting results related to the prevention of viral infections, reduction of the duration of diseases, and decrease of symptoms.
\end{abstract}

Keywords: probiotic; gut microbiota; viral infection; viruses; influenza

\section{Introduction}

The mammalian intestine is a complex ecosystem, as it is a point of symbiosis between the host and approximately $10^{14}$ types of resident microorganisms, which have been acquired even before birth and continue to exist throughout life [1]. This community of microorganisms is often called gut microbiota (GM) [2,3]. The microbiome includes the microorganisms and their genetic material, which importantly contributes to host physiology by providing genetic elements that are not already present in the host genome [4]. Among GM microbes, some species can confer beneficial effects to the physiology and metabolism of the host. Among them, the Food and Agriculture Organization of the United Nations [5] defined the term probiotic as "live microorganisms, which when consumed in adequate amounts, confer a health effect on the host." Probiotics are live bacteria that can be given as a supplement or in a food product that, if ingested in an adequate amount, can provide benefits to the host. Probiotics are composed mainly of lactic acid bacteria (LAB) and complex carbohydrate fermenters, which are part of the normal GM of humans and animals. Supplementation with probiotics can provide benefits to the host directly 
by preventing infection, or indirectly by enhancing the immune response of the host. There is scientific evidence that consumption of probiotics can play a role in increasing defense against external pathogens, thus maintaining the balance of the intestinal immune system $[6,7]$.

Viral infectious diseases nowadays have a great impact on humankind. Viral infections produce variable morbidity and mortality, negatively affecting community health and causing wide economic losses [8]. The best example of this global threat may be the infectious disease caused by the new Severe Acute Respiratory Syndrome Coronavirus 2 (SARS-CoV-2), which during the 2019-2020 pandemic has infected millions of people worldwide [8]. Consequently, it is important to find alternative and safe ways to prevent viral infections and reduce the morbidity and mortality of viral infections. Even partially effective therapies for the treatment and prevention of viral infections can reduce the mortality, morbidity, and economic losses caused by these infections [9].

A large number of antiviral drugs that may be effective in certain infections are now available; however, the appearance of new viral strains through mutations is a major threat. Although combination therapies of drugs are effective against several viral diseases, it is always desirable to have additional approaches that may be used as preventives or supplemental therapies [10]. Among different strategies to prevent and reduce viral infections, adequate nutrition, including nutrients or food ingredients that enhance and potentiate immune response, are useful alternatives to reduce the number of infections and their severity. One nutritional strategy used in recent years to improve human immunity and reduce the ability to be infected is the intake of probiotics [11].

The main objective of this work was to provide a literature review of the effects of probiotic agents in the prevention and reduction of the severity of symptoms in viral infections, with special emphasis on the most recently published works.

\section{Probiotics and the Immune System}

According to the FAO consensus [5], criteria for probiotic bacteria include that the bacterial strain: (1) Must be able to survive in the gastrointestinal tract and proliferate in the intestine; (2) must benefit the host through growth or activity in the human body; (3) must be non-toxic and non-pathogenic; (4) must provide protection against pathogenic microorganisms that employ multiple mechanisms; and (5) must lack transferable antibiotic resistance. Bacterial strains of the same genus and species can have completely different effects on the host. Given this, the search for probiotic agents has evolved, and now it is even feasible to modify probiotics with increasingly complex functionalities by transferring mobile genetic elements [12]. Because probiotics can possess antiviral activity, they can be chosen as alternatives to or complementary antiviral therapies [13]. Although nowadays there is a significant demand for bioactive components such as probiotics in Western countries, consumers are reluctant to change their dietary habits [14]. Although in some cases probiotic products were developed by pharmaceutical industry, they have become increasingly popular among the public due to their inclusion in functional foods, generating wider acceptance among consumers [15]. This suggests that there is great potential for foods that are consumed regularly when they are converted to functional foods [14], that show better consumer acceptance than pharmacological presentations.

The most common genus of microbes used as probiotics are LAB, such as Lactobacillus [1], and primary oligosaccharide fermenters such as Bifidobacterium [16], although other genera, and even yeast, such as Saccharomyces, were proposed and used as probiotic agents [1]. One mechanism that probiotic strains, known as immunobiotics, can provide to human or animal health is modulating the mucosal and systemic immune systems $[17,18]$, thus protecting against infectious diseases, including viral infections [13,19].

The consumption of probiotics has different beneficial effects on human health such as the production of antimicrobial and anti-adhesion substances against pathogens, thus facilitating the modulation of the immune system [20]. Probiotic bacteria can also inhibit the adhesion of the invading virus to the host-cell receptor by binding to it [13]. Moreover, 
probiotics can exert antiviral activity by direct probiotic-virus interaction, production of metabolites with antiviral inhibitory activity, or by stimulating the immune system of the host [13]. Probiotics may indirectly interfere with the virus by altering the state of cells, stimulating innate and adaptive immunity, or enhancing or suppressing associated molecular signaling pathways [21]. Probiotic bacteria can also have a protective effect against virus particles competing for adhesion to the cell surface. This has been tested in vitro and reported as a useful mechanism for cell protection in case of mucosal virus infections [22]. Another way of actuation of probiotics is the regulation of innate immunity using toll receptors and different signaling pathways, thus reducing inflammatory processes [23]. This regulation in innate immune system of the host can be kept increasing phagocytic activity, the activity of leukocytes (polymorphonuclears and monocytes), the expression of some receptors that are associated with phagocytosis, and the microbicidal function of neutrophils [13]. Different scientific studies showed that viruses, when they enter the body, activate an innate immune response where the inflammasomes are responsible for destroying the pathogens. The immune system detects pathogens in multiple ways, and there are two first-line of defense systems against viruses: The production of Type I interferons and interleukins (IL) IL-1 $\beta$ and IL-18 by inflammasomes. On the one hand, type I interferons promote an antiviral state in the infected host, and on the other hand, cytokines, including IL, induce inflammatory processes and modulate immune responses, producing antiviral effects [24]. For this reason, probiotic bacteria can regulate the activation of the inflammasome in organisms that have previously suffered inflammation due to viral infections. [24].

Another beneficial effect of probiotics is their capacity to help mature and activate the mucosal immune system by secreting metabolites such as organic acid, short chain fatty acids (SCFA), hydrogen peroxide, coagulation molecules, and bacteriocins, which are antimicrobial compounds $[25,26]$. These metabolites, particularly SCFAs, influence the gut epithelial and immune cells directly, enhancing the immune response. It was demonstrated that SCFAs reduced pattern recognition receptor (PRR) stimulation through activation of activated B-cell nuclear factor kappa-light-chain-enhancer and tumor necrosis factoralpha $(\mathrm{TNF} \alpha)$ [27]. In in vitro alveolar macrophages, it has been seen that the induction of low-level synthesis of nitric oxide can also influence the protective action of probiotic bacteria against viruses in respiratory cells [28]. Many studies have demonstrated that probiotics can increase the CD4+ lymphocytes count and regulate TNF- $\alpha$, IL-6, IL-8, IL-10, and IL-12 [26].

\section{Major Viruses Involved in Human Diseases}

Nowadays, there are up to 200 species of viruses that can infect humans, and their number is increasing at a rate of 3-4 per year [29]. Consequently, most new human pathogens are viruses, and it is common for the virus to be of animal origin. A substantial proportion of mammalian viruses may cross the species barrier reaching humans. However, only a small number of these have human-to-human transmission and are therefore capable of causing human outbreaks. It will be practically inevitable that new human viruses will continue to emerge, and thus, an effective global surveillance system for new viruses is needed [29].

Although viruses can cause a wide variety of infections in different organs and systems of the human body, viruses were split, for this literature review, into three groups: Respiratory viruses, digestive viruses, and other viruses. Acute viral respiratory infections are among the leading causes of death worldwide, accounting for more than 4 million deaths per year [11]. In addition, these viruses are a leading cause of pediatric morbidity and mortality worldwide because of the immature immune system of the babies. On the other hand, the elderly are more susceptible to serious complications due to their weakened immune system [11].

These viruses spread easily between humans due to airborne transmission through aerosols, causing outbreaks that are very difficult to control [30]. Viral respiratory pathogens 
belong to various virus families, so RNA-containing viruses are more significant: Picornaviridae, Orthomyxoviridae, Paramyxoviridae, Reoviridae, Coronaviridae, and DNA-containing viruses, such as Adenoviridae and Parvoviridae [11,31]. Individuals can also be infected simultaneously with multiple viruses, and in some cases, multiple viruses have synergistic effects against host health [11,27].

Regarding viral gastrointestinal infections, different viruses, such as rotavirus (RV), norovirus (NV), or calicivirus (CV; including the agent Norwalk and astrovirus), can infect the human gastrointestinal tract and are responsible for many illnesses related to childhood diarrhea and gastroenteritis outbreaks worldwide [20]. These viruses have uncoated RNA, which makes them highly infectious and are transmitted in a fecal-oral manner. These infections are usually mild to moderate in severity and short in duration [32]. Rotavirus was traditionally the most common cause of severe dehydrating diarrhea in children, estimated to cause approximately 200,000 deaths in children under five years of age each year [19]. After the large-scale implementation of RV vaccines, $\mathrm{NV}$ is now the leading cause of severe diarrhea in children in developed countries and is also considered the most common cause of foodborne illness, nowadays associated with approximately $18 \%$ of gastroenteritis cases worldwide [32]. Astroviruses account for 2-9\% of pediatric gastroenteritis cases worldwide [32]. There are enteric viruses that replicate in the gastrointestinal tract but are asymptomatic, such as reovirus or poliovirus, that can cause severe disease after spreading to peripheral tissues [32].

Another important group of viral infections affecting humans worldwide are liver infections. Among them, enterically-transmitted Hepatitis A (HAV), Hepatitis B virus (HBV), Hepatitis C virus (HCV), and Hepatitis E (HEV) viruses are causes of acute viral hepatitis in humans $[33,34]$. These viruses are transmitted through various routes, such as blood transfusions, sexual contact, and consumption of water or food contaminated by feces. HAV use the latter route for transmission; therefore, their outbreaks are more common in underdeveloped countries [35].

Skin viral infections include a large variety of viral agents, among which herpes zoster, which is caused by the reactivation in adults of the varicella-zoster virus, stands out. Herpes viruses can cause a primary infection, establish a latent infection in a specific set of cells in their host, and then reactivate when immunity weakens [36]. One of the most common members of the herpes virus family is cytomegalovirus (CMV), and more than $80 \%$ of primary infections occur in transplants. Herpes simplex virus (HSV) mainly affects the genital and perioral regions [36]. Another virus that causes human skin infections is the human papillomavirus (HPV), which presents several different types of warts, depending on the infected surface and its relative humidity, and pressure patterns [37]. Human papillomavirus represents a diverse group of viruses that primarily infect epithelial and mucosal tissues [38]. Polyomaviruses have been suspected as potential etiological agents in human skin cancer. These viruses infect epithelial tissues throughout the body, producing benign and malignant lesions, including common and genital warts [39].

Concerning viruses that can cause neurological infections, rabies virus (RABV) is one of the diseases that has been known since the beginning of civilization and has caused much fear. According to the World Health Organization [40], more than 59,000 and 21,476 deaths have been recorded worldwide and in Africa, respectively, due to this virus. Rabies is a disease of zoonotic origin caused by neurotropic viruses and is mostly spread by rabid animals, belongs to the genus lyssavirus, family Rhabdoviridae [41]. Other viral neurological infections are caused by arboviruses, which include several families of viruses that are transmitted by arthropod vectors. The arbovirus group includes Flaviviridae, Togaviridae, Bunyaviridae, and Reoviridae families that possess a high capacity to adapt rapidly to changing environmental and host conditions [42]. On the other hand, the most common cause of epidemic viral encephalitis in the United States today is West Nile virus infection. The incidence of this virus has increased significantly since 2008, especially in southern Europe. This and other mosquito-borne flaviviruses are considered endemic in Europe, such as Usutu virus [43]. 
There are also a large variety of hematological viruses, which cause infections with hemorrhagic fevers, that are RNA viruses encased in a lipid bilayer derived from the host's cell membrane [44]. Viral hemorrhagic fevers are typically endemic in some regions, can cause large outbreaks, and have high mortality rates. They are characterized by an acute febrile syndrome with hemorrhages and affect both humans and animals [44,45].

\section{Probiotic Usage against Respiratory Viruses}

It has been demonstrated that the intestinal microbiota affects the health of the lungs due to the direct relationship between the microbiota and the lungs, known as the "gut-lung axis". This axis is bidirectional, so endotoxins and microbial metabolites can affect the lung through the blood, and on the other hand, when inflammation takes place in the lung it can affect the intestinal bacteria [23]. Previous studies have found respiratory infections that are related with a change in the composition of the GM [23]. For example, mice with influenza viral infections in their respiratory tract have increased Enterobacteriaceae and reduced Lactobacillus and Lactococcus in their GM [46]. Secreted metabolites and immunomodulatory signals, such as secondary bile acids, secreted by commensal bacteria bind to their receptors in innate cells, such as macrophages, stimulating their metabolism and functions [23]. Additionally, it was demonstrated in murine models that removing some bacterial species from the GM by antibiotic treatments leads to an increased risk of influenza virus [46].

Disrupting the adhesion of the virus to mucosal cells could be beneficial to the host. Probiotic bacteria could bind directly to the virus, producing this disruption [25]. However, despite the abovementioned results about probiotic bacteria in the prevention and treatment of respiratory viral infections, nowadays there is no clear consensus about this matter, because on the one hand there are clinical trials that demonstrate the benefit of the use of probiotics in respiratory infections, but other clinical trials did not obtain any advantage after probiotic bacteria usage.

An important meta-analysis, with more than 8000 preterm infants included in several clinical trials, demonstrated that patients receiving enteral supplementation with probiotics showed a reduction in mortality caused by respiratory infections [47]. Viruses are especially important in respiratory tract infections because they cause more than $90 \%$ of upper respiratory tract infections [48]. The previous works regarding the effect of probiotic supplementation on viral respiratory infections is shown in Table 1. In most cases, the trials investigating this relationship were performed in mouse models [49-63], but some were also in clinical trials with children [64-68], adults volunteers [9,69-77], and the elderly $[78,79]$. The probiotic bacteria employed to prevent respiratory viral infections, in most cases, were Lactobacillus strains. However, other bacterial genera were also employed, such as Clostridium [69], Bacillus [69], Enterococcus [69], Bifidobacterium [25,65,67,68,77,80], Streptococcus [81], and Propionibacterium [67].

The lack of consensus on probiotic strains/gender may be due to differences in studies conducted and outcomes reported measures, the length of intervention, study populations used (children vs. adults), bacterial dose $\left(10^{6}-10^{10} \mathrm{CFU} /\right.$ day), or different matrices (milk, yogurt, capsules) used. Additionally, decreased immunity due to aging may partly explain the conflicting results in the elderly [9]. For instance, it was demonstrated that specific strains of lactobacilli could bind and inactivate flu-like respiratory virus in vitro [9]. Probiotic lactobacilli were reported to protect against respiratory tract infections by modifying innate and acquired host immune responses [50]. Additionally, a concrete lactobacilli strain (L. plantarum DK119) can prevent influenza A H1N1 and H3N2 infections and mortality in a mouse model, promoting innate host immunity to influenza infection by modulating alveolar macrophages and dendritic cells [51]. 
Table 1. Effects of probiotics against respiratory viruses.

\begin{tabular}{|c|c|c|c|c|c|}
\hline Type of Study & Probiotics & $\begin{array}{l}\text { Dosage and Time of } \\
\text { Exposure }\end{array}$ & Viruses & Main Findings & Reference \\
\hline $\begin{array}{l}\text { In vivo using female } \\
\mathrm{BALB} / \mathrm{c} \text { mice }\end{array}$ & $\begin{array}{c}140 \text { different strains of } \\
\text { lactic acid bacteria } \\
\text { (LAB) }\end{array}$ & $\begin{array}{c}120 \mathrm{mg} \mathrm{LAB} / \text { day for } 28 \\
\text { days }\end{array}$ & $\begin{array}{c}\text { Influenza A/X/31 } \\
\text { (H3N2) virus }\end{array}$ & $\begin{array}{l}\text { Lactobacillus plantarum } \\
\text { AYA protects against } \\
\text { respiratory influenza } \\
\text { virus infection and } \\
\text { decreased influenza } \\
\text { lethality in mice }\end{array}$ & [49] \\
\hline $\begin{array}{l}\text { In vivo using } 13 \\
\text { female BALB/c mice }\end{array}$ & $\begin{array}{c}\text { Lyophilized } \\
\text { Lactobacillus rhamnosus } \\
\text { GG (LGG) and } \\
\text { Lactobacillus gasseri } \\
\text { TMC0356 }\end{array}$ & $\begin{array}{c}10 \mathrm{mg} \text { of lyophilized } \\
\text { LGG and L. gasseri for } \\
19 \text { days }\end{array}$ & $\begin{array}{c}\text { Influenza virus } \\
\mathrm{A} / \mathrm{PR} / 8 / 34 \text { (H1N1) }\end{array}$ & $\begin{array}{l}\text { The clinical symptom } \\
\text { scores and pulmonary } \\
\text { virus titers of mice } \\
\text { administered oral LGG } \\
\text { and L. gasseri were } \\
\text { significantly ameliorated }\end{array}$ & [50] \\
\hline $\begin{array}{l}\text { In vivo using } 96 \\
\text { elderly volunteers }\end{array}$ & $\begin{array}{c}\text { Yogurt fermented } \\
\text { with Lactobacillus } \\
\text { delbrueckii ssp. } \\
\text { bulgaricus } \\
\text { OLL1073R-1 } \\
\text { (1073R-1-yogurt) }\end{array}$ & $\begin{array}{l}100 \mathrm{~g} \text { of } 1073 \mathrm{R}-1 \text {-yogurt } \\
\text { for } 12 \text { weeks }\end{array}$ & $\begin{array}{c}\text { Influenza A virus } \\
\text { subtype H3N2-bound }\end{array}$ & $\begin{array}{c}\text { Consumption of } \\
\text { fermented yogurt } \\
\text { affected influenza A virus } \\
\text { subtype H3N2-bound } \\
\text { Immunoglobulin A (IgA) } \\
\text { levels in saliva. }\end{array}$ & [78] \\
\hline $\begin{array}{l}\text { In vivo trial using } \\
\text { female BALB/c mice }\end{array}$ & L. plantarum DK 119 & $\begin{array}{c}\text { Intragastric } \\
\text { administration }(200 \mu \mathrm{L} \\
\text { of } 10^{8}-10^{9} \text { colony count } \\
\text { units }(\mathrm{CFU}) \text { daily for } 10 \\
\text { days }) \text { or intranasal } \\
\left(10^{7}-10^{9} \mathrm{CFU} / \text { mouse }\right)\end{array}$ & $\begin{array}{l}\mathrm{H} 1 \mathrm{~N} 1 \text { and } \mathrm{H} 3 \mathrm{~N} 2 \\
\text { influenza viruses }\end{array}$ & $\begin{array}{l}\text { L. plantarum protects } \\
\text { against infection with } \\
\text { H1N1 and H3N2 } \\
\text { influenza viruses by } \\
\text { enhancing the innate } \\
\text { immunity of CD11c+ } \\
\text { dendritic and } \\
\text { macrophage cells and } \\
\text { antiviral cytokines }\end{array}$ & [51] \\
\hline $\begin{array}{l}\text { In vivo using female } \\
\mathrm{BALB} / \mathrm{c} \text { mice }\end{array}$ & L. plantarum $06 \mathrm{CC} 2$ & $\begin{array}{l}20 \mathrm{mg} / \text { mouse, twice } \\
\text { daily for } 10 \text { days }\end{array}$ & $\begin{array}{c}\text { Influenza A/PR/8/34 } \\
\text { (H1N1) virus }\end{array}$ & $\begin{array}{c}\text { L. plantarum relieved } \\
\text { influenza symptoms in } \\
\text { mice in correlation with } \\
\text { increased NK cell activity } \\
\text { associated with increased } \\
\text { production of } \\
\text { interferon- } \alpha \text { and Th1 } \\
\text { cytokines through gut } \\
\text { immunity and reduction } \\
\text { of TNF- } \alpha \text { in the early } \\
\text { stage of infection }\end{array}$ & [52] \\
\hline $\begin{array}{l}\text { In vivo using } 15 \\
\text { patients }\end{array}$ & $\begin{array}{l}\text { Clostridium butyricum } \\
\text { CBM588, Bacillus } \\
\text { subtilis (unspecified } \\
\text { strain), and } \\
\text { Enterococcus faecium } \\
\text { (unspecified strain) }\end{array}$ & $\begin{array}{c}\text { Two tablets of probiotic } \\
\text { compound were } \\
\text { administered three } \\
\text { times per day } \\
\left(\sim 10^{7} \mathrm{CFU} / \text { tablet for }\right. \\
\text { CBM588 and } 10^{8} \mathrm{CFU} \\
\text { for B. subtilis and } E \text {. } \\
\text { faecium enteric-coated } \\
\text { capsules }\end{array}$ & Influenza virus H7N9 & $\begin{array}{l}\text { No beneficial effects have } \\
\text { been seen in the } \\
\text { administration of } C \text {. } \\
\text { butyricum against H7N9 } \\
\text { infection. Administration } \\
\text { of } B \text {. subtilis and } E \text {. } \\
\text { faecium improved the } \\
\text { secondary infection. }\end{array}$ & [69] \\
\hline $\begin{array}{l}\text { In vivo using specific } \\
\text { pathogen-free female } \\
\text { BALB/c mice }\end{array}$ & $\begin{array}{l}\text { L. rhamnosus M21 } \\
\text { (KCTC 10965BP) }\end{array}$ & $\begin{array}{c}\text { Oral administration of } \\
0.3 \mathrm{~mL} \text { of } \\
1 \times 10^{9} \mathrm{CFU} / \mathrm{mL} \text { of } \\
\text { L. rhamnosus }\end{array}$ & $\begin{array}{c}\text { Influenza virus } \\
\text { A/NWS/3 } 3 \text { (H1N1) }\end{array}$ & $\begin{array}{l}\text { L. rhamnosus increases the } \\
\text { production of IgA and } \\
\text { decreases the recruitment } \\
\text { of inflammatory cells in } \\
\text { the lungs, thus exhibiting } \\
\text { anti-influenza activity by } \\
\text { changing the host } \\
\text { response to Th1 }\end{array}$ & [53] \\
\hline $\begin{array}{l}\text { Clinical trial in in } \\
272 \text { subjects }\end{array}$ & $\begin{array}{l}\text { L. plantarum HEAL } 9 \\
\text { (DSM 15312) and } \\
\text { Lactobacillus paracasei } \\
\text { 8700:2 (DSM 13434) }\end{array}$ & $\begin{array}{c}\text { Subjects were } \\
\text { supplemented daily } \\
\text { with either } 10^{9} \mathrm{CFU} \text { of } \\
\text { probiotics for } 12 \text { weeks }\end{array}$ & Common cold viruses & $\begin{array}{l}\text { Oral intake of the strains } \\
\text { L. plantarum and } \\
\text { L. paracasei decreases the } \\
\text { total symptom score and } \\
\text { especially the pharyngeal } \\
\text { symptoms of common } \\
\text { cold infections }\end{array}$ & [70] \\
\hline
\end{tabular}


Table 1. Cont.

\begin{tabular}{|c|c|c|c|c|c|}
\hline Type of Study & Probiotics & $\begin{array}{c}\text { Dosage and Time of } \\
\text { Exposure }\end{array}$ & Viruses & Main Findings & Reference \\
\hline $\begin{array}{c}\text { Clinical trial in } 233 \\
\text { volunteers }\end{array}$ & L. paracasei N1115 & $\begin{array}{l}\text { Volunteers were given } \\
\text { 100-mL bottles of } \\
\text { yogurt, which } \\
\text { contained living } \\
\text { L. paracasei } 3.6 \times 10^{9} \\
\text { CFU, three bottles per } \\
\text { day for } 12 \text { weeks }\end{array}$ & $\begin{array}{l}\text { Viruses causing upper } \\
\text { respiratory tract } \\
\text { infections }\end{array}$ & $\begin{array}{l}\text { The intake of yogurt } \\
\text { containing L. paracasei } \\
\text { could protect against the } \\
\text { risk of acute upper } \\
\text { respiratory tract infection } \\
\text { in the mid-aged and } \\
\text { elderly, might be that } \\
\text { L. paracasei stimulated } \\
\text { T-cell immunity }\end{array}$ & [71] \\
\hline $\begin{array}{l}\text { Clinical trial in } 136 \\
\text { subjects }\end{array}$ & $\begin{array}{c}\text { L. paracasei, } \\
\text { Lactobacillus casei } 431, \\
\text { and Lactobacillus } \\
\text { fermentum PCC }\end{array}$ & $\begin{array}{c}\text { All subjects received } \\
\text { once-daily doses of } \\
\text { probiotic drink (150 } \\
\mathrm{mL}) \text { that contained } \\
\text { L. paracasei at } \\
3 \times 10^{7} \mathrm{CFU} / \mathrm{mL}, \\
\mathrm{L.casei} \text { at } \\
3 \times 10^{7} \mathrm{CFU} / \mathrm{mL} \text {, and } \\
\mathrm{L} . \mathrm{fermentum} \text { at } \\
3 \times 10^{6} \mathrm{CFU} / \mathrm{mL} \text { or } \\
\text { placebo drink for } 12 \\
\text { weeks }\end{array}$ & $\begin{array}{l}\text { Viruses causing upper } \\
\text { respiratory tract } \\
\text { infections and influenza } \\
\text { virus }\end{array}$ & $\begin{array}{l}\text { Administration of these } \\
\text { probiotics increased the } \\
\text { levels of serum INF-g } \\
\text { and IgA in the intestine. } \\
\text { Reduced flu-like } \\
\text { symptoms and the } \\
\text { incidence of respiratory } \\
\text { tract infection }\end{array}$ & [72] \\
\hline $\begin{array}{l}\text { In vivo using female } \\
\text { BALB/c mice }\end{array}$ & $\begin{array}{c}\text { L. paracasei } \mathrm{CNCM} \\
\mathrm{I}-1518\end{array}$ & $\begin{array}{c}\text { Mice were orally } \\
\text { gavaged }(200 \mu \mathrm{L}) \text { with } \\
\text { L. paracasei }\left(2 \times 10^{8}\right. \\
\text { CFU) daily for } 7 \text { days } \\
\text { before infection }\end{array}$ & $\begin{array}{c}\text { Influenza } \\
\text { A/Scotland/20/74 } \\
\text { (H3N2) virus }\end{array}$ & $\begin{array}{l}\text { L. paracasei consumption } \\
\text { seems to allow an early } \\
\text { activation of } \\
\text { proinflammatory } \\
\text { cytokines (IL1 } \alpha, \text { IL-1 } \beta \text { ) } \\
\text { and a massive } \\
\text { recruitment of immune } \\
\text { cells in the lungs after } \\
\text { L. paracasei gavage and } \\
\text { before influenza infection }\end{array}$ & [54] \\
\hline
\end{tabular}

Lactobacillus

acidophilus CUL21

(NCIMB 30156), L.

acidophilus CUL60

(NCIMB 30157)

Clinical trial in 69 Bifidobacterium bifidum children
$1.25 \times 10^{10} \mathrm{CFU}$ of probiotics plus $50 \mathrm{mg}$ vitamin $C$ or a placebo daily for 6 months
Viruses causing upper respiratory tract infections

Reduced incidence rate of respiratory tract infection symptoms in the probiotic group.

Bifidobacterium

animalis subsp. lactis

CUL34 (NCIMB

30172)

\begin{tabular}{|c|c|c|c|c|c|}
\hline $\begin{array}{c}\text { Clinical trial in } 1000 \\
\text { volunteers }\end{array}$ & $\begin{array}{l}\text { Lactobacillus casei } \\
\text { DN-114 } 001\end{array}$ & $200 \mathrm{~g} /$ day for 3 months & $\begin{array}{l}\text { Respiratory common } \\
\text { infectious diseases }\end{array}$ & $\begin{array}{l}\text { Reduced the risk of } \\
\text { common infections in } \\
\text { stressed individuals such } \\
\text { as shift workers }\end{array}$ & [81] \\
\hline $\begin{array}{l}\text { Clinical trial in } 94 \\
\text { preterm infants }\end{array}$ & $\begin{array}{l}\text { L. rhamnosus GG } \\
\text { ATCC } 53103\end{array}$ & $\begin{array}{c}1 \times 10^{9} \mathrm{CFU} / \text { day for } 1 \\
\text { to } 30 \text { days and } \\
2 \times 10^{9} \mathrm{CFU} / \text { day for } 31 \\
\text { to } 60 \text { days }\end{array}$ & $\begin{array}{l}\text { Adenovirus, coronavirus } \\
\text { (229E/NL63 and } \\
\text { OC43/HKU1), influenza } \\
\text { A and B, Human } \\
\text { metapneumovirus, } \\
\text { parainfluenza 1, 2, and 3, } \\
\text { RSV A and B, rhinovirus, } \\
\text { Human enterovirus and } \\
\text { bocavirus }\end{array}$ & $\begin{array}{l}\text { The incidence of } \\
\text { respiratory tract } \\
\text { infections was lower in } \\
\text { the probiotic group. The } \\
\text { incidence of rhinovirus } \\
\text { was significantly lower in } \\
\text { the probiotic group. } \\
\text { Incidence of } \\
\text { rhinovirus-induced } \\
\text { episodes tended to be } \\
\text { lower in the prebiotic but } \\
\text { not in the probiotic group }\end{array}$ & [66] \\
\hline
\end{tabular}


Table 1. Cont.

\begin{tabular}{|c|c|c|c|c|c|}
\hline Type of Study & Probiotics & $\begin{array}{l}\text { Dosage and Time of } \\
\text { Exposure }\end{array}$ & Viruses & Main Findings & Reference \\
\hline $\begin{array}{l}\text { Clinical trial in } 629 \\
\text { otitis-prone children }\end{array}$ & $\begin{array}{l}\text { L. rhamnosus GG, } L . \\
\text { rhamnosus Lc705, } \\
\text { Bifidobacterium breve } \\
\text { 99, and } \\
\text { Propionibacterium } \\
\text { freudenreichii JS }\end{array}$ & $\begin{array}{c}8-9 \times 10^{9} \mathrm{CFU} / \text { day for } \\
6 \text { months }\end{array}$ & $\begin{array}{l}\text { Human bocavirus } 1-4 \text { and } \\
\text { rhinovirus/enterovirus }\end{array}$ & $\begin{array}{l}\text { Lower number of human } \\
\text { bocavirus } 1 \text { positive } \\
\text { sample during the study, } \\
\text { but no effect on } \\
\text { rhinovirus/enterovirus } \\
\text { occurrence }\end{array}$ & [67] \\
\hline $\begin{array}{l}\text { Clinical trial in } 210 \\
\text { children }\end{array}$ & $\begin{array}{l}\text { B. animalis subsp. } \\
\text { lactis (BB-12) }\end{array}$ & $\begin{array}{c}10^{9} \mathrm{CFU} / \text { day for } 3 \\
\text { months }\end{array}$ & $\begin{array}{l}\text { Respiratory common } \\
\text { infectious diseases }\end{array}$ & $\begin{array}{l}\text { This study shows that } B . \\
\text { animalis subsp. lactis has } \\
\text { no effect on the } \\
\text { prevention of respiratory } \\
\text { tract infection in children. } \\
\text { There was no significant } \\
\text { difference in the number } \\
\text { of people infected or in } \\
\text { the duration of infection } \\
\text { in the intervention group } \\
\text { and the placebo group }\end{array}$ & [68] \\
\hline $\begin{array}{l}\text { Clinical trial in } 97 \\
\text { daycare children }\end{array}$ & L. rhamnosus GG & $\begin{array}{c}10^{8} \mathrm{CFU} / \text { day for } 28 \\
\text { weeks }\end{array}$ & $\begin{array}{l}\text { Human bocavirus 1-4, } \\
\text { rhinovirus/enterovirus, } \\
\text { RSV, adenovirus, } \\
\text { influenza A, and PIV 1-2 }\end{array}$ & $\begin{array}{l}\text { Respiratory symptoms } \\
\text { decreased in children per } \\
\text { month, but there was no } \\
\text { effect on the occurrence } \\
\text { of respiratory viruses }\end{array}$ & [82] \\
\hline $\begin{array}{l}\text { Clinical trial in } 192 \\
\text { adults }\end{array}$ & $\begin{array}{l}\text { L. rhamnosus GG + B. } \\
\text { lactis } \mathrm{BB}-12\end{array}$ & $\begin{array}{c}5 \times 10^{9} \mathrm{CFU} \text { of GG and } \\
2 \times 10^{9} \text { of } \\
\text { BB-12 CFU/day for } 3 \text { to } \\
6 \text { months }\end{array}$ & $\begin{array}{c}\text { Human bocavirus, } \\
\text { rhinovirus/enterovirus, } \\
\text { RSV A and B, adenovirus, } \\
\text { coronavirus (229E/NL63 } \\
\text { and OC43/HKU1), } \\
\text { influenza A and B virus, } \\
\text { human metapneumovirus, } \\
\text { and PIV 1-4. }\end{array}$ & $\begin{array}{l}\text { Lower occurrence of } \\
\text { rhinovirus/enterovirus } \\
\text { after } 3 \text { months, but no } \\
\text { significant effect on the } \\
\text { occurrence of common } \\
\text { respiratory viruses }\end{array}$ & [25] \\
\hline $\begin{array}{l}\text { Clinical trial in } 209 \\
\text { adults }\end{array}$ & L. plantarum DR7 & $\begin{array}{c}9 \log \text { CFU / day for } 12 \\
\text { weeks }\end{array}$ & $\begin{array}{l}\text { Viruses causing upper } \\
\text { respiratory tract } \\
\text { infections }\end{array}$ & $\begin{array}{c}\text { Reducing plasma } \\
\text { peroxidation and } \\
\text { oxidative stress levels }\end{array}$ & [74] \\
\hline $\begin{array}{l}\text { Two clinical trials in } \\
86 \text { and } 222 \text { elderly } \\
\text { volunteers }\end{array}$ & L. casei DN 114001 & $\begin{array}{l}\text { Dairy drink }\left(\text { Actimel }^{\circledR}\right) \\
\text { for } 7 \text { and } 13 \text { weeks }\end{array}$ & $\begin{array}{c}\text { Influenza A (H1N1 and } \\
\text { H3N2) and B }\end{array}$ & $\begin{array}{l}\text { Daily consumption of } \\
\text { this product resulted in } \\
\text { increased specific } \\
\text { antibody responses to } \\
\text { influenza virus } \\
\text { vaccination in persons } \\
\text { over } 70 \text { years of age }\end{array}$ & [79] \\
\hline $\begin{array}{l}\text { In vivo using BALB/c } \\
\text { mice (number not } \\
\text { specified) }\end{array}$ & $\begin{array}{l}\text { L. rhamnosus } \\
\text { (unespecified strain) }\end{array}$ & $\begin{array}{c}\text { Sublingually } \\
\text { administered at } 10^{8}, \\
10^{7} \text {, and } \\
10^{6} \mathrm{CFU} / \text { mouse for } 3,6, \\
10,13 \text {, and } 16 \text { days }\end{array}$ & $\begin{array}{c}\text { Influenza A/NWS/33 } \\
\text { (H1N1) }\end{array}$ & $\begin{array}{c}\text { Sublingual } \\
\text { administration of } \\
\text { L. rhamnosus increases the } \\
\text { production of IgA in the } \\
\text { secretion of the mucosa } \\
\text { and the activity of T cells } \\
\text { and natural killer cells, } \\
\text { providing protection } \\
\text { against flu virus }\end{array}$ & [55] \\
\hline $\begin{array}{l}\text { Clinical trial in } 42 \\
\text { healthy adults }\end{array}$ & L. rhamnosus GG & $\begin{array}{l}\text { Capsules containing } \\
1 \times 10^{10} \text { CFU twice } \\
\text { daily for } 28 \text { days }\end{array}$ & $\begin{array}{c}\text { Influenza A (H1N1 and } \\
\text { H3N2) and B }\end{array}$ & $\begin{array}{l}\text { On day 28, a significant } \\
\text { increase in seroprotection } \\
\text { in the LGG group for the } \\
\text { H3N2 vaccine strain was } \\
\text { found }\end{array}$ & [75] \\
\hline
\end{tabular}


Table 1. Cont.

\begin{tabular}{|c|c|c|c|c|c|}
\hline Type of Study & Probiotics & $\begin{array}{l}\text { Dosage and Time of } \\
\text { Exposure }\end{array}$ & Viruses & Main Findings & Reference \\
\hline $\begin{array}{l}\text { In vivo using BALB/c } \\
\text { mice (number not } \\
\text { specified) }\end{array}$ & $\begin{array}{l}\text { L. rhamnosus GG } \\
\text { (ATCC 53103) }\end{array}$ & $\begin{array}{c}\text { Intranasally } \\
\text { administered at } 20 \mu \mathrm{L} \\
\text { of LGG solution/day } \\
\text { for three days }\end{array}$ & $\begin{array}{c}\text { Influenza A/PR/8/34 } \\
\text { (PR8, H1N1) }\end{array}$ & $\begin{array}{l}\text { Intranasal administration } \\
\text { of LGG enhances } \\
\text { respiratory cell-mediated } \\
\text { immune responses by } \\
\text { following the activation } \\
\text { of natural killer cells in } \\
\text { the lungs, thus protecting } \\
\text { the host from IFV } \\
\text { infection }\end{array}$ & [56] \\
\hline $\begin{array}{l}\text { In vivo using } 40 \\
\mathrm{BALB} / \mathrm{c} \text { mice }\end{array}$ & $\begin{array}{l}\text { Lactobacillus pentosus } \\
\text { strain b240 }\end{array}$ & $\begin{array}{c}\text { Oral administration of } \\
\text { non-viable heat-killed } \\
\text { b40 diluted at doses of } \\
0.4,2 \text {, or } \\
10 \mathrm{mg} / \text { mouse/day for } \\
22 \text { days. }\end{array}$ & $\begin{array}{c}\text { Influenza A/PR8/34 } \\
\text { (H1N1) }\end{array}$ & $\begin{array}{c}\text { Orally administered } \\
\text { L. pentosus reduces } \\
\text { influenza virus infectious } \\
\text { titers in the lungs of } \\
\text { influenza virus-infected } \\
\text { mice }\end{array}$ & [57] \\
\hline $\begin{array}{l}\text { In vivo using BALB/c } \\
\text { mice ( } 5-6 \text { per group) }\end{array}$ & L. rhamnosus CRL1505 & $\begin{array}{l}\text { Two consecutive days } \\
\text { of } 10^{8} \mathrm{CFU} / \text { mouse/day } \\
\text { inoculated via nostrils } \\
\text { using live and } \\
\text { heat-killed } \\
\text { L. rhamnsosus }\end{array}$ & $\begin{array}{c}\text { Influenza A/PR/8/34 } \\
(\mathrm{H} 1 \mathrm{~N} 1)\end{array}$ & $\begin{array}{l}\text { Both viable and } \\
\text { non-viable } L . \text { rhamnsosus } \\
\text { reduced lung injury and } \\
\text { viral load, protecting } \\
\text { infected mice }\end{array}$ & [58] \\
\hline $\begin{array}{l}\text { In vivo using BALB/c } \\
\text { mice (number not } \\
\text { specified) }\end{array}$ & L. pentosus S-PT84 & $\begin{array}{c}\text { Intranasal } \\
\text { administration of } 20 \mu \mathrm{L} \\
\text { of } L \text {. pentosus at a } \\
\text { concentration of } 0,1 \text {, or } \\
10 \mathrm{mg} / \mathrm{mL} \text { once daily } \\
\text { for } 3 \text { consecutive days }\end{array}$ & $\begin{array}{c}\text { Influenza A/PR/8/34 } \\
\text { (PR8, H1N1) }\end{array}$ & $\begin{array}{l}\text { Intranasal administration } \\
\text { of } L \text {. pentosus protected } \\
\text { against flu virus infection } \\
\text { by enhancing Th } \\
\text { immunity, induction of } \\
\text { INF- } \alpha \text { and natural killer } \\
\text { activity }\end{array}$ & [59] \\
\hline $\begin{array}{l}\text { In vivo using BALB/c } \\
\text { mice (number not } \\
\text { specified) }\end{array}$ & $\begin{array}{l}\text { Bifidobacterium longum } \\
\text { MM-2 }\end{array}$ & $\begin{array}{c}\text { Orally administered of } \\
2 \times 10^{9} \mathrm{CFU} / \text { day for } 17 \\
\text { days from } 14 \text { days } \\
\text { before } 2 \text { days after IFV } \\
\text { infection }\end{array}$ & $\begin{array}{c}\text { Influenza A/PR/8/1934 } \\
\text { (PR8, H1N1) }\end{array}$ & $\begin{array}{l}\text { Oral administration of } B . \\
\text { longum stimulates } \\
\text { immunity by increasing } \\
\text { the activity of natural } \\
\text { killer cells in the lungs } \\
\text { and spleen, resulting in } \\
\text { muffled viral } \\
\text { proliferation. This } \\
\text { probiotic suppresses } \\
\text { inflammation in the } \\
\text { lower respiratory tract, } \\
\text { reduces symptoms, and } \\
\text { improves the survival } \\
\text { rate of IFV-infected mice }\end{array}$ & [60] \\
\hline $\begin{array}{l}\text { In vivo using } 60 \\
\text { BALB/c mice }\end{array}$ & $\begin{array}{l}\text { Lactobacillus brevis } \\
\text { JCM } 17312\end{array}$ & $\begin{array}{c}1 \times 10^{9} \mathrm{CFU} / \text { day for } 14 \\
\text { days }\end{array}$ & $\begin{array}{c}\text { Influenza A/PR/8/34 } \\
\text { (H1N1) }\end{array}$ & $\begin{array}{l}\text { L. brevis increases the } \\
\text { production capacity of } \\
\text { INF- } \alpha \text { and the increase of } \\
\text { the production of specific } \\
\text { IgA of the human } \\
\text { immunodeficiency virus, } \\
\text { which can improve the } \\
\text { symptomatology of this } \\
\text { infection }\end{array}$ & [61] \\
\hline $\begin{array}{l}\text { Clinical trial in } 50 \\
\text { volunteers }\end{array}$ & $\begin{array}{l}\text { L. fermentun } \\
\text { CECT5716 }\end{array}$ & $\begin{array}{c}\text { Oral daily dose of } \\
1 \times 10^{10} \text { CFU } 2 \text { weeks } \\
\text { before vaccination and } \\
2 \text { weeks after } \\
\text { vaccination }\end{array}$ & $\begin{array}{c}\text { Influenza A (H1N1 } \\
\text { and H3N2) }\end{array}$ & $\begin{array}{l}\text { In the probiotic group } \\
\text { there was an increase in } \\
\text { the production of natural } \\
\text { killer cells, two weeks } \\
\text { after vaccination. In } \\
\text { addition, the } \\
\text { antigen-specific IgA was } \\
\text { also increased. The } \\
\text { incidence of } \\
\text { influenza-like illness was } \\
\text { lower in this group } 5 \\
\text { months after vaccination }\end{array}$ & [76] \\
\hline
\end{tabular}


Table 1. Cont

\begin{tabular}{|c|c|c|c|c|c|}
\hline Type of Study & Probiotics & $\begin{array}{l}\text { Dosage and Time of } \\
\text { Exposure }\end{array}$ & Viruses & Main Findings & Reference \\
\hline $\begin{array}{l}\text { Clinical trial in } 211 \\
\text { subjects }\end{array}$ & $\begin{array}{l}\text { B. animalis ssp. lactis } \\
\text { BB-12(DSM15954), } \\
\text { L. paracasei ssp. } \\
\text { paracasei, L. casei } 431 \\
\text { (ATCC 55544) }\end{array}$ & $\begin{array}{l}\text { The probiotic products } \\
\text { contained a minimum } \\
\text { of } 1 \times 10^{9} \mathrm{CFU} / \text { day for } \\
6 \text { weeks }\end{array}$ & Influenza A virus & $\begin{array}{c}\text { Both probiotic groups } \\
\text { increased specific IgG } \\
\text { and mean fold for } \\
\text { vaccine specific secretory } \\
\text { IgA in saliva }\end{array}$ & {$[77]$} \\
\hline $\begin{array}{l}\text { In vivo using } \\
\text { C57BL/6N mice } \\
\text { (number not } \\
\text { specified) }\end{array}$ & L. gasseri SBT2055 & $\begin{array}{l}\text { Orally administered of } \\
\text { L. gasseri at } 1 \times 10^{8} \text { or } \\
1.6 \times 10^{9} \mathrm{CFU} / \text { mouse/day } \\
\text { for } 21 \text { days }\end{array}$ & Influenza A virus (PR8) & $\begin{array}{l}\text { Oral administration of } \\
\text { L. gasseri improved the } \\
\text { survival rates and the } \\
\text { titer of the virus in the } \\
\text { lungs, thus making the } \\
\text { mice stronger against a } \\
\text { viral infection }\end{array}$ & {$[62]$} \\
\hline $\begin{array}{l}\text { In vivo using BALB/c } \\
\text { mice (number not } \\
\text { specified) }\end{array}$ & L. pentosus b240 & $\begin{array}{c}\text { Orally administered } \\
\text { heat-killed } L \text {. pentosus } \\
\text { every day at a dose of } \\
10 \mathrm{mg} / \text { mouse }\left(10^{10}\right) \text { for } \\
5 \text { weeks }\end{array}$ & Influenza A (H1N1) & $\begin{array}{c}\text { Expression of antiviral } \\
\text { genes in rodent lungs can } \\
\text { be regulated by } \\
\text { administration of } \\
\text { L. pentosus }\end{array}$ & {$[63]$} \\
\hline
\end{tabular}

Genera other than Lactobacillus were employed as probiotic mixtures and not individually. In most cases, probiotics were applied against influenza virus infections, with the exceptions of Kumpu et al. [64], Luoto et al. [66], and Garaiova et al. [65], who investigated various viruses, Berggren et al. [70], who investigated probiotic effects against cold infections, and Guillemard et al. [73], who investigated effects against rhinopharyngitis. It is normal that the effects against influenza viruses have been the most investigated virus because the influenza virus produces a respiratory infection that is a major cause of morbidity and mortality worldwide, and new influenza subtypes become more dangerous to society. Studies have shown that oral and intranasal administration of LAB protects against this virus. In addition, LAB, such as certain species of Lactobacillus and Bifidobacterium, have been reported to modulate systemic and mucosal immune responses, mainly by improving mucosal Immunoglobulin A (IgA) production [49].

Additionally, due to the SARS-Cov2 pandemic, the effects of probiotics against this disease were recently investigated. One of the serious clinical manifestations of COVID-19, especially in the elderly and immunosuppressed, is pneumonia and the severity of acute respiratory distress syndrome [83], children suffer less severe symptoms [84]. Thus, it is reasonable to think that improving innate immunity could be useful in reducing the severity of this infection.

\section{Probiotic Usage against Digestive Viruses}

It is well known that some probiotics can prevent infections in the gastrointestinal tract and infections in other organs [48]. The main viruses that are involved in human diarrhea are rotavirus (RV), calicivirus (CaV; which includes norovirus (NV) and sapovirus (SAP)), enteric adenovirus, and astrovirus. Of these, $\mathrm{RV}$ and $\mathrm{CaV}$ are responsible for most cases of severe gastroenteritis [2]. RV is transmitted through contact between humans and responsible for one-third of the cases of severe diarrhea in children under five years old around the world [2]. Enteric viruses can be classified into two different mechanisms. One type multiplies in the intestinal epithelium, such as RV, which cause gastroenteritis, and the other type multiplies in the intestine, such as enteroviruses, but spreads to target organs, causing serious diseases [2].

In recent years, it has been shown that several LAB strains exert protection against infections produced by enteric viruses, increasing the production of specific antibodies and shortening the episodes of diarrhea [85,86]. Among its protective effects produced are mechanisms, such as increased immune defenses of the host and the production of antibiotic-like substances, $\operatorname{IgA}$, and cytokine stimuli [86]. These probiotic strains have also been shown to increase mucosal secretions, improve intestinal motility, or enhance the 
productions of SCFA that act as protectors for the gut. There are also studies indicating that probiotic bacteria may have effects on the maturation of intestinal macrophages and dendritic cells and enhance cytokine production [86].

Table 2 shows different studies on the effect of probiotics and prebiotics against viruses that cause digestive diseases. These studies have been carried out both in vitro using cells lines $[6,7,85,87,88]$ and in vivo using mouse models $[80,89,90]$ and humans $[91,92]$. For these purposes, single Lactobacillus [88,90] or Bifidobacterium [80], but more frequently, mixtures of these two LAB with different bacterial genera, including also Streptococcus [87,92], and Enterococcus [7], were used. With respect to viral agents, the most common viral infections investigated were $\mathrm{RV}[6,7,79,89,92]$, transmissible gastroenteritis coronavirus (TGEV) [7,88], or murine NV [90].

Table 2. Effects of probiotics against digestive viruses.

\begin{tabular}{|c|c|c|c|c|c|}
\hline Type of Study & Probiotics & $\begin{array}{l}\text { Dosage and Time of } \\
\text { Exposure }\end{array}$ & Viruses & Main Findings & Reference \\
\hline $\begin{array}{l}\text { In vitro using a bovine } \\
\text { intestinal epithelial cell } \\
\text { line originally derived } \\
\text { from fetal bovine } \\
\text { intestinal epitheliocytes }\end{array}$ & $\begin{array}{l}\text { Lactobacillus gasseri } \\
\text { TMC0356, Lactobacillus } \\
\text { rhamnosus (LGG), } \\
\text { L. rhamnosus LA-2, } \\
\text { Lactobacillus casei TMC0409, } \\
\text { Streptococcus thermophilus } \\
\text { TMC1543, Bifidobacterium } \\
\text { bifidum 2-2, and B. bifidum 3-9 }\end{array}$ & $\begin{array}{c}\text { Lactobacilli or } \\
\text { bifidobacteria } \\
\left(5 \times 10^{7} \text { cells } / \mathrm{mL}\right) \text { for } \\
24 \text { or } 48 \mathrm{~h}\end{array}$ & $\begin{array}{l}\text { Enteric common } \\
\text { infectious diseases }\end{array}$ & $\begin{array}{l}\text { Administration of L. rhamnosus } \\
\text { induces the activation of TLR3, } \\
\text { and there is an increase in the } \\
\text { production of IFN- } \beta \text { by bovine } \\
\text { intestinal epithelial cells, which } \\
\text { may have beneficial effects on the } \\
\text { protection against enteric viruses } \\
\text { in vivo }\end{array}$ & [87] \\
\hline $\begin{array}{l}\text { In vitro using intestinal } \\
\text { and } \\
\text { monocyte/macrophage- } \\
\text { derived cell lines } \\
\text { (human, pig, goat) }\end{array}$ & $\begin{array}{l}\text { L. rhamnosus (LGG), L. casei, } \\
\text { Enterococcus faecium PCK38, } \\
\text { Lactobacillus fermentum } \\
\text { ACA-DC179, Lactobacillus } \\
\text { pentosus PCA227, and } \\
\text { Lactobacillus plantarum } \\
\text { PCA236 and PCS22 }\end{array}$ & $\begin{array}{l}10^{8} \mathrm{CFU} / \mathrm{mL} \text { and } \\
\text { incubated for } 24-48 \mathrm{~h}\end{array}$ & $\begin{array}{l}\text { Rotavirus (RV) } \\
\text { and transmissible } \\
\text { gastroenteritis } \\
\text { coronavirus } \\
\text { (TGEV) }\end{array}$ & $\begin{array}{l}\text { Administration of lactic acid } \\
\text { bacteria (LAB) shows a protective } \\
\text { effect against VR and TGEV. In } \\
\text { the case of L. casei, Shirota has a } \\
\text { high level of protection against } \\
\text { TGEV by releasing highly reactive } \\
\text { oxygen species (ROS) into the } \\
\text { TLT cell line. } L \text {. plantarum } \\
\text { PCA236 also stimulated the } \\
\text { release of these reactive species }\end{array}$ & [7] \\
\hline $\begin{array}{l}\text { In vitro using a porcine } \\
\text { intestinal epithelial cell } \\
\text { line (PIE cells) }\end{array}$ & $\begin{array}{c}\text { Bifidobacterium longum } \\
\text { MCC1, Bifidobacterium } \\
\text { infantis MCC12, } \\
\text { Bifidobacterium breve MCC16, } \\
\text { B. pseudolongum MCC92, } \\
\text { Lactobacillus paracasei } \\
\text { MCC1375, L. gasseri } \\
\text { MCC587, and Lactococcus } \\
\text { lactis sub ssp. lactis MCC } 866\end{array}$ & $\begin{array}{l}\text { The cultured cells } \\
\text { were incubated with } \\
\text { different LAB strains } \\
\text { at a density of } \\
5 \times 10^{8} \text { cells } / \mathrm{mL} \text { for } \\
48 \mathrm{~h} \text {. }\end{array}$ & RV & $\begin{array}{l}\text { B. infantis MCC } 12 \text { and B. breve } \\
\text { MCC1274 increased the } \\
\text { production of INF- } \beta \text { in PIE cells, } \\
\text { in response to VR infection. They } \\
\text { also increased the expression of } \\
\text { CXCL10 and IL- } 6 \text { genes, } \\
\text { especially the } B \text {. infantis }\end{array}$ & [6] \\
\hline In vitro using PIE cells & $\begin{array}{l}\text { L. rhamnosus CRL1505 and } \\
\text { L. plantarum CRL1506 }\end{array}$ & $\begin{array}{c}\text { Lactobacilli } \\
\left(5 \times 10^{8} \text { cells } / \mathrm{mL}\right) \\
\text { were added, and } 48 \mathrm{~h} \\
\text { later effects were } \\
\text { determined }\end{array}$ & & $\begin{array}{l}\text { Antiviral factors and } \\
\text { cytokines/chemokines were } \\
\text { increased in lactobacilli-treated } \\
\text { PIE cells. The expression of the } \\
\text { IL-15 and RAE1 genes that } \\
\text { mediate poly (I:C) inflammatory } \\
\text { damage was also reduced }\end{array}$ & [85] \\
\hline $\begin{array}{l}\text { In vivo using pregnant } \\
\text { BALB / c mice }\end{array}$ & B. bifidum G9-1 (BBG9-1) & $\begin{array}{l}\text { Orally administration } \\
\text { of } 3 \times 10^{7} \text { CFU of } \\
\text { BBG9-1, respectively, } \\
\text { once daily for } 10 \text { days } \\
\text { from } 2 \text { days before to } \\
7 \text { days after RV } \\
\text { infection }\end{array}$ & RV & $\begin{array}{l}\text { The oral administration of } B \text {. } \\
\text { bifidum induced mucosal } \\
\text { protective factors, protecting } \\
\text { against RV-induced lesions, and } \\
\text { improving diarrhea. B. bifidum } \\
\text { may be an effective method to } \\
\text { control an RV epidemic for } \\
\text { prophylactic and therapeutic } \\
\text { purposes }\end{array}$ & [80] \\
\hline
\end{tabular}


Table 2. Cont.

\begin{tabular}{|c|c|c|c|c|c|}
\hline Type of Study & Probiotics & $\begin{array}{l}\text { Dosage and Time of } \\
\text { Exposure }\end{array}$ & Viruses & Main Findings & Reference \\
\hline In vivo using mice & $\begin{array}{l}\text { Human-derived Lactobacillus } \\
\text { reuteri DSM } 17938 \text { and ATCC } \\
\text { PTA } 6475\end{array}$ & $\begin{array}{c}\text { Diluted to a } \\
\text { concentration of } \\
2 \times 10^{9} \mathrm{CFU} / \mathrm{mL} \text { in } \\
\text { PBS. Mice received } \\
\text { gastric gavages } \\
(50 \mu \mathrm{L}) \text { of probiotics } \\
\text { or vehicle daily from } \\
\text { days } 5 \text { to } 14 \text { of life. }\end{array}$ & RV & $\begin{array}{l}\text { A decrease in proinflammatory } \\
\text { cytokine concentrations was seen, } \\
\text { including the inflammatory } \\
\text { protein of macrophages-1a and } \\
\text { IL-1b, as well as an increase in the } \\
\text { specific antibodies against } \\
\text { rotavirus after the administration } \\
\text { of the two probiotic strains. } L \text {. } \\
\text { reuteri reduced diarrhea episodes }\end{array}$ & [89] \\
\hline In vitro in ST cells & $\begin{array}{l}\text { L. plantarum Probio-38 and L. } \\
\text { salivarius Probio-37 }\end{array}$ & $10^{8}$ to $10^{9} \mathrm{CFU} / \mathrm{mL}$ & TGEV & $\begin{array}{l}\text { Both strains survived in synthetic } \\
\text { gastric juice and inhibited TGE } \\
\text { coronavirus in vitro in ST cells }\end{array}$ & [88] \\
\hline $\begin{array}{l}\text { In vivo using } 49 \\
\text { children }\end{array}$ & $\begin{array}{l}\text { L. casei subsp. casei strain GG } \\
\text { (LGG), L. casei subsp. } \\
\text { rhamnosus (Lactophilus), or a } \\
\text { combination of S. } \\
\text { thermophilus and L. delbrückii } \\
\text { subsp. bulgaricus (Yalacta }{ }^{\circledR} \text { ) }\end{array}$ & Twice daily for 5 days & RV & $\begin{array}{l}\text { Administration of LGG increased } \\
\text { the cells secreting specific IgA } \\
\text { antibodies to rotavirus and in the } \\
\text { convalescence stage. In addition, } \\
\text { the duration of diarrhea was } \\
\text { reduced in children }\end{array}$ & [92] \\
\hline In vivo using 12 mice & L. paracasei ATCC 334 & $10^{8}$ CFU for 6 days & $\begin{array}{l}\text { Murine norovirus } \\
\text { (NV) }\end{array}$ & $\begin{array}{l}\text { Intake of L. paracasei before the } \\
\text { infection by murine NV, reduced } \\
\text { the level of expression of the } \\
\text { mRNA that encodes the viral } \\
\text { polymerase }\end{array}$ & [90] \\
\hline $\begin{array}{l}\text { Clinical trial in } 816 \\
\text { children }\end{array}$ & $\begin{array}{l}\text { L. rhamnosus R0011 and } \\
\text { Lactobacillus helveticus R0052 }\end{array}$ & $\begin{array}{l}\quad 4 \times 10^{9} \text { CFU of } \\
\text { L. rhamnosus and } \\
\text { L. helveticus ( } 95: 5 \text { ratio) } \\
\text { twice daily for } 5 \text { days }\end{array}$ & $\begin{array}{l}\text { Adenovirus, } \\
\text { norovirus, and } \\
\text { rotavirus }\end{array}$ & $\begin{array}{l}\text { No beneficial effects associated } \\
\text { with the administration of } \\
\text { L. rhamnosus and L. helveticus have } \\
\text { been observed; these probiotics } \\
\text { do not reduce the severity of } \\
\text { acute gastroenteritis or expedite } \\
\text { the clearance of viruses in stool }\end{array}$ & [91] \\
\hline
\end{tabular}

As can be seen in Table 2, all the probiotic treatments demonstrated different degrees of protection against viral infections by different mechanisms, such as stimulating interferons, interleukins of Ig production, or accelerating reactive oxygen species (ROS) depletion in tissues. In some cases, probiotic strains also benefited the host against viral infection via genetic regulations modifying the expression of mRNA encoding viral polymerase [90] or genes involved in the inflammatory response [85].

\section{Probiotics against Other Viruses}

As was previously defined, there are a large variety of viruses that can cause other types of infections besides respiratory or digestive infections. Unfortunately, many of these cause very serious diseases that probiotics, and even in some cases the most modern medical technologies, cannot solve. However, for viruses that cause hepatitis, skin virus infections, human immunodeficiency virus (HIV), or HPV, probiotics could directly or indirectly, help reduce their symptoms or prevent infection

Table 3 shows the probiotic effects on the symptoms of other viral infections that were performed in mouse models [21,93], monkeys [22], or humans [26,94-100]. The trials performed investigated the effects of $\mathrm{LAB}$, but also other less frequent species, such as Enterococcus [94], Escherichia [22], or even yeast, such as Saccharomyces [93]. With respect to viral infections, these probiotic agents were employed to improve the symptomatology of viral infections, such as HCV ([93], HPV [21,26,95,96], HIV [22,97,98], or herpes simplex virus (HSV) type I [22,93]. 
Table 3. Effects of probiotics against other viruses.

\begin{tabular}{|c|c|c|c|c|c|}
\hline Type of Study & Probiotics & $\begin{array}{l}\text { Dosage and Time of } \\
\text { Exposure }\end{array}$ & Viruses & Main Findings & Reference \\
\hline $\begin{array}{c}\text { In vivo trial in } 39 \\
\text { patients serologically } \\
\text { positive for } \\
\text { anti-hepatitis C virus } \\
\text { (HCV) IgG antibodies }\end{array}$ & Enterococcus faecalis FK-23 & $\begin{array}{l}900 \mathrm{mg} \text { of E. faecalis } \\
3 \text { times daily }\end{array}$ & $\mathrm{HCV}$ & $\begin{array}{l}\text { E. faecalis decreased } \\
\text { alanine transferase } \\
\text { from } 3 \text { to } 26 \text { months of } \\
\text { treatment while } \\
\text { maintaining viral } \\
\text { charge and other } \\
\text { enzyme levels }\end{array}$ & [94] \\
\hline $\begin{array}{l}\text { Clinical trial in } 180 \\
\text { women }\end{array}$ & $\begin{array}{c}\text { Lactobacillus rhamnosus GR-1 } \\
\text { and Lactobacillus reuteri RC-14 } \\
\text { (50\% each) }\end{array}$ & $\begin{array}{c}180 \text { mg including } 5.4 \times 10^{9} \\
\text { CFU once a day until } \\
\text { negative human } \\
\text { papillomavirus }(\mathrm{HPV}) \\
\text { result }\end{array}$ & HPV & $\begin{array}{l}\text { This probiotic may } \\
\text { have decreased } \\
\text { abnormal cervical } \\
\text { smear rates, but it did } \\
\text { not influence the } \\
\text { genital burden of HPV }\end{array}$ & [26] \\
\hline $\begin{array}{l}\text { Clinical trial in } 117 \\
\text { women }\end{array}$ & $\begin{array}{l}\text { L. rhamnosus BMX } 54 \text { after a } \\
\text { standard treatment of } 500 \mathrm{mg} \\
\text { metronidazole twice a day for } \\
7 \text { days }\end{array}$ & $\begin{array}{l}\text { Vaginal tablets of } \\
10^{4} \text { CFU / tablet one each } 3 \\
\text { days for } 20 \text { days and then } \\
\text { once every } 5 \text { days for } 2 \\
\text { months (short treatment), } \\
\text { or once a week for } 5 \\
\text { months (long treatment) }\end{array}$ & HPV & $\begin{array}{c}\text { Probiotic } \\
\text { implementation for } 6 \\
\text { months favors the } \\
\text { recreation of the vaginal } \\
\text { balance, and therefore it } \\
\text { can be useful to control } \\
\text { the infection by the } \\
\text { human papilloma virus }\end{array}$ & [95] \\
\hline $\begin{array}{l}\text { Clinical trial in } 54 \\
\text { women }\end{array}$ & Lactobacillus casei Shirota & $\begin{array}{l}\text { Daily consumption of a } \\
\text { commercially available } \\
\left.\text { probiotic (Yakult }{ }^{\circledR}\right)\end{array}$ & HPV & $\begin{array}{c}\text { The likelihood of } \\
\text { clearance of low-grade } \\
\text { squamous } \\
\text { intraepithelial lesion } \\
\text { abnormalitieswas twice } \\
\text { as high in the probiotic } \\
\text { group }\end{array}$ & [96] \\
\hline $\begin{array}{l}\text { Clinical trial in } 8 \text { human } \\
\text { immunodeficiency } \\
\text { virus (HIV)-positive } \\
\text { patients }\end{array}$ & $\begin{array}{l}\text { Mix of Lactobacillus plantarum } \\
\text { DSM24730, Streptococcus } \\
\text { thermophilus DSM24731, } \\
\text { Bifidobacterium breve } \\
\text { DSM24732, Lactobacillus } \\
\text { paracasei DSM24733, } \\
\text { Lactobacillus delbrueckii subsp } \\
\text { bulgaricus DSM24734, } \\
\text { Lactobacillus acidophilus DSM } \\
\text { 24735, Bifidobacterium longum } \\
\text { DSM24736, andBifidobacterium } \\
\text { infantis DSM24737) }\end{array}$ & $\begin{array}{c}1.8 \times 10^{12} \mathrm{CFU} \text { twice a day } \\
\text { for } 6 \text { months }\end{array}$ & HIV & $\begin{array}{l}\text { Administration of these } \\
\text { probiotics decreases the } \\
\text { level of tryptophan in } \\
\text { plasma and increases } \\
\text { the concentration of } \\
\text { serotonin in the blood }\end{array}$ & [97] \\
\hline $\begin{array}{l}\text { In vitro trial in Vero } \\
\text { African green monkey } \\
\text { kidney cells }\end{array}$ & $\begin{array}{l}\text { L. rhamnosus PTCC } 1637 \text { and } \\
\text { Escherichia coli PTCC } 25923\end{array}$ & $1 \times 10^{8} \mathrm{CFU} / \mathrm{mL}$ & $\begin{array}{c}\text { Herpes } \\
\text { simplex } \\
\text { virus-1 } \\
\text { (HSV-1) }\end{array}$ & $\begin{array}{c}\text { L. rhamnosus through } \\
\text { various mechanisms, } \\
\text { such as competition } \\
\text { with the virus for } \\
\text { adhesion to cells or } \\
\text { increased viability of } \\
\text { macrophages, induced } \\
\text { antiviral effects against } \\
\text { HSV-1 }\end{array}$ & [22] \\
\hline $\begin{array}{l}\text { In vivo using } 15 \text { female } \\
\text { C57BL } / \text { mice }\end{array}$ & $\begin{array}{l}\text { Bifidobacterium bifidum } \\
\text { (unespecified strain) }\end{array}$ & $\begin{array}{l}5 \text { groups of } 10 \text {, treatment } \\
\text { groups were administrated } \\
\text { either orally or } \\
\text { intravenously with } 100 \mu \mathrm{L} \\
\text { B. bifidum }\left(1 \times 10^{8} \mathrm{CFU}\right) 5 \\
\text { times at a } 4 \text {-day interval } \\
\text { for } 20 \text { days, including } 2 \\
\text { times before and after } \\
\text { tumor induction and one } \\
\text { time on the same day of } \\
\text { the challenge }\end{array}$ & $\mathrm{HPV}$ & $\begin{array}{l}\text { Administration of this } \\
\text { probiotic orally or } \\
\text { intravenously, can } \\
\text { modulate the immune } \\
\text { system by stimulating } \\
\text { secretion of INF-y and } \\
\text { IL-12 in spleen cells and } \\
\text { Th1 responses and } \\
\text { prevent tumor growth }\end{array}$ & [21] \\
\hline
\end{tabular}


Table 3. Cont.

\begin{tabular}{|c|c|c|c|c|c|}
\hline Type of Study & Probiotics & $\begin{array}{l}\text { Dosage and Time of } \\
\text { Exposure }\end{array}$ & Viruses & Main Findings & Reference \\
\hline $\begin{array}{c}\text { Clinical trial in } 65 \\
\text { women with confirmed } \\
\text { HIV infection }\end{array}$ & $\begin{array}{l}\text { L. rhamnsosus GR-1 and } \\
\text { L. reuteri } \mathrm{RC}-14\end{array}$ & $\begin{array}{c}\text { Daily capsules of } \\
\text { freeze-dried probiotics } \\
\text { with } 2 \times 10^{9} \mathrm{CFU} \text { and } \\
\quad 400 \mathrm{mg} \text { of oral } \\
\text { metronidazole twice daily } \\
\text { for } 10 \text { days in women } \\
\text { diagnosed with bacterial } \\
\text { vaginosis }\end{array}$ & HIV & $\begin{array}{l}\text { Administration of these } \\
\text { probiotics can improve } \\
\text { the quality of life of } \\
\text { women with } \\
\text { HIV-induced BV, but } \\
\text { not cure it. }\end{array}$ & [98] \\
\hline $\begin{array}{l}\text { Clinical trial in } 14 \\
\text { children }\end{array}$ & L. plantarum $299 \mathrm{v}$ & $\begin{array}{l}\text { lyophilized powder in an } \\
\text { oatmeal base in } 5 \mathrm{~g} \text { for } \\
3 \text { months }\end{array}$ & HIV & $\begin{array}{l}\text { Probiotic bacteria can } \\
\text { have protective effects } \\
\text { against inflammation } \\
\text { and activation of the } \\
\text { gastrointestinal } \\
\text { immune system by } \\
\text { stabilizing the number } \\
\text { of CD4+ T cells }\end{array}$ & [99] \\
\hline $\begin{array}{l}\text { Clinical trial in } 39 \\
\text { subjects }\end{array}$ & L. reuteri MM2 & $\begin{array}{c}1 \times 10^{10} \mathrm{UFC} / \text { day for } \\
21 \text { days }\end{array}$ & HIV & $\begin{array}{c}\text { No effects were } \\
\text { detected in either safety } \\
\text { or tolerance parameters }\end{array}$ & [100] \\
\hline In vivo using male mice & $\begin{array}{c}\text { Saccharomyces boulardii } \\
\text { CNCM I-745 }\end{array}$ & $\begin{array}{l}\text { Oral gavage with either } S \text {. } \\
\text { boulardii ( } 10^{7} \mathrm{CFU} / \text { day) for } \\
4 \text { weeks }\end{array}$ & HSV-1 & $\begin{array}{c}\text { These probiotic } \\
\text { increased levels of } \\
\text { anti-inflammatory } \\
\text { interleukins, decreased } \\
\text { production of } \\
\text { pro-inflammatory } \\
\text { cytokines, and } \\
\text { improved HSV-1 }\end{array}$ & [93] \\
\hline
\end{tabular}

Regarding hepatitis infections, there are different studies that support the idea of including probiotics in routine therapy to fight fatigue, nausea, and low appetite, which are secondary effects of hepatitis C drug treatment [94]. An imbalance in intestinal microbiota has been seen in individuals with liver cirrhosis. Thus, for this reason, modifying the GM with probiotic supplements can decrease endotoxins and other compounds derived from bacteria, such as ethanol, phenol, and indoles, which are toxic and cause liver damage [94].

In HIV prevention, various observational studies have shown probiotic supplementation can prevent bacterial vaginosis caused by Gardnerella vaginalis and Mycoplasma hominis, a condition that facilitates the transmission of HIV [98]. Gori et al. [101] showed that in HIV-positive patients, there is usually a gastrointestinal deterrent at the beginning of the disease. This symptom is associated with, among other things, the GM disorders, which confirms a possible correlation between GM, gastrointestinal mucosal damage, and the immune system [102]. In HIV-positive people, there occurs an alteration of total microbial colonization as well as the microbiota composition in the oral cavity, and decreased CD4+ $\mathrm{T}$ cell counts have been associated with the presence of oral lesions [102]. Additionally, an intestinal disorder with pro-inflammatory effects has often been seen [97] with the increase in GM of either pro-inflammatory or potentially pathogenic bacterial populations, such as Pseudomonas aeruginosa and Candida albicans, whereas there is a reduction in beneficial bacterial counts such as Bifidobacterium and Lactobacillus [102]. An elegant review recently reported [103] investigated the effects of probiotics on inflammation markers in HIV patients, with no clear results due to the generally limited power of the studies included, that in most cases must be considered only exploratory.

Other authors reported that the prevailing HIV-associated dysbiosis across several cohorts seems to consist of enrichment of the phylum Proteobacteria including several subtaxa containing pathogenic bacteria, combined with a depletion of taxa within the bacterial families Ruminococcaea and Lachnospiracea, known producers of SCFA [103]. A modification of the activity of the enzyme indoleamine 2,3-dioxygenase 1 induced by the interferon has also been described, which produces alterations in the tryptophan 
metabolism pathway [97]. These findings support the hypothesis that alterations in the gastrointestinal tract are a very important factor in the pathogenesis of HIV infection. In a study by Sheri et al. [97], it was shown that a mixture of probiotics, combined with IL-21, reduced the expression of several markers that activate CD4+ T cells. Because of this, it was suggested that probiotics act on the signaling of toll-like receptors (TLRs). Another important factor in the use of probiotics among HIV patients is that GM is crucial for the normal development of gut-associated lymphoid tissue (GALT), essential to ensure an appropriate immune activity [102].

However, the use of probiotics in severe immunocompromised or severely debilitated patients, such as HIV or recently transplanted patients [104]. HIV infection, at least during later stages, is associated with increased gut permeability and loss of local host immunity in GALT that may predispose to invasive infections. Thus, it was previously identified at least 11 single cases of patients, who after Lactobacillus supplementation suffered invasive Lactobacillus infections, causing symptoms such as bacteremia, pneumonia, or empyema, and even causing one documented death [104]. The risk of probiotics in immunocompromised people varies based on their contents, being L. rhamnosus the riskiest Lactobacillus species [105].

The idea of oral administration of probiotics against vaginal infections came from the knowledge that many urogenital infections arise from the entrance of a pathogen from the rectum to the perianal skin and then the vagina [106]. The mechanisms of action of probiotics at vaginal level include acidification of the mucosal surface, prevention of the adherence of pathogens, production of substances such as vitamins an immune modulators, and synergistic action with the host immune system [106]. Palma et al. [95] reported that HPV clearance was higher with the treatment of metronidazole and six months vaginal Lactobacillus implementation. On the other hand, Verhoeven et al. [96] previously failed to find any influence of probiotics on HPV clearance in a group of women with HPVrelated low-grade squamous intraepithelial lesion using oral Lactobacillus casei Shirota $\left(1 \times 10^{10} \mathrm{CFU} /\right.$ day $)$ for six months.

\section{Conclusions}

Recently published studies show the beneficial effects of using various probiotics to treat different diseases caused by viruses. Although they do not cure diseases, these probiotics are beneficial to patients because, in some cases, they improve the immune system and reduce the number of days of illness and the symptoms of the disease. Given the results obtained, probiotics can be an alternative for the prevention and treatment of many viral diseases that cause so many deaths around the world each year, or at least improve the quality of life of patients suffering from these diseases. Especially, there is great potential for probiotics consumed through functional foods, that seen to show better consumer acceptance than pharmacological presentations. There is a profound need for more in-depth studies into the benefits of the administration of probiotics in viral infections.

Author Contributions: Conceptualization, J.M.M. and A.C. Literature data collection, A.L.-S., A.d.C.M., P.R. and J.A.R.-A. Writing-original draft, A.L.-S. and A.L. Writing-review and editing, A.C.-C., C.M.F., and A.L. Supervision: J.M.M. and A.C. All authors have read and agreed to the published version of the manuscript.

Funding: The authors thank the European Regional Development Funds (FEDER), grant ED431C 2018/05, and Programa Iberoamericano de Ciencia y Tecnología para el Desarrollo (CyTED), grant PCI2018-093245 for covering the cost of publication.

Institutional Review Board Statement: Not applicable.

Informed Consent Statement: Not applicable.

Data Availability Statement: The data presented in this study are available on request from the corresponding author. The data are not publicly available due to privacy concerns.

Conflicts of Interest: The authors declare no conflict of interest. 


\section{References}

1. Lopez-Santamarina, A.; Miranda, J.M.; Mondragon, A.C.; Lamas, A.; Cardelle-Cobas, A.; Franco, C.M.; Cepeda, A. Potential use of marine seaweeds as prebiotics: A review. Molecules 2020, 25, 1004. [CrossRef] [PubMed]

2. Colbère-Garapin, F.; Martin-Latil, S.; Blondel, B.; Mousson, L.; Pelletier, I.; Autret, A.; François, A.; Niborski, V.; Grompone, G.; Catonnet, G.; et al. Prevention and treatment of enteric viral infections: Possible benefits of probiotic bacteria. Microbes Infect. 2007, 9, 1623-1631. [CrossRef] [PubMed]

3. Libertucci, J.; Young, V.B. The role of the microbiota in infectious diseases. Nat. Microbiol. 2019, 4, 35-45. [CrossRef] [PubMed]

4. Hall, A.B.; Tolonen, A.C.; Xavier, R.J. Human genetic variation and the gut microbiome in disease. Nat. Rev. Genet. 2017, 18, 690-699. [CrossRef]

5. FAO/WHO Food and Agriculture Organization of the United Nations/World Health Organization. Guidelines for the Evaluation of Probiotics in Food. Report of a Joint FAO/WHO Working Group on Drafting Guidelines for the Evaluation of Probiotics in Food. 2002. Available online: https://www.who.int/foodsafety/fs_management/en/probiotic_guidelines.pdf (accessed on 21 November 2020).

6. Ishizuka, T.; Kanmani, P.; Kobayashi, H.; Miyazaki, A.; Soma, J.; Suda, Y.; Aso, H.; Nochi, T.; Iwabuchi, N.; Xiao, J.-z.; et al. Immunobiotic bifidobacteria strains modulate rotavirus immune response in porcine intestinal epitheliocytes via pattern recognition receptor signaling. PLoS ONE 2016, 11, e0152416. [CrossRef]

7. Maragkoudakis, P.A.; Chingwaru, W.; Gradisnik, L.; Tsakalidou, E.; Cencic, A. Lactic acid bacteria efficiently protect human and animal intestinal epithelial and immune cells from enteric virus infection. Int. J. Food Microbiol. 2010, 141, S91-S97. [CrossRef]

8. Villena, J.; Shimosato, T.; Vizoso-Pinto, M.G.; Kitazawa, H. Editorial: Nutrition, immunity and viral infections. Front. Nutr. 2020, 7, 125. [CrossRef]

9. $\quad$ Lehtoranta, L.; Kalima, K.; He, L.; Lappalainen, M.; Roivainen, M.; Närkiö, M.; Mäkelä, M.; Siitonen, S.; Korpela, R.; Pitkäranta, A. Specific probiotics and virological findings in symptomatic conscripts attending military service in Finland. J. Clin. Virol. 2014, 60, 276-281. [CrossRef]

10. Merry, T.; Astrautsova, S. Alternative approaches to antiviral treatments: Focusing on glycosylation as a target for antiviral therapy. Biotechnol. Appl. Biochem. 2010, 56, 103-109. [CrossRef]

11. Lehtoranta, L.; Latvala, S.; Lehtinen, M.J. Role of probiotics in stimulating the immune system in viral respiratory tract infections: A narrative review. Nutrients 2020, 12, 3163. [CrossRef]

12. Aggarwal, N.; Breedon, A.M.E.; Davis, C.M.; Hwang, I.Y.; Chang, M.W. Engineering probiotics for therapeutic applications: Recent examples and translational outlook. Curr. Opin. Biotechnol. 2020, 65, 171-179. [CrossRef] [PubMed]

13. Sundararaman, A.; Ray, M.; Ravindra, P.V.; Halami, P.M. Role of probiotics to combat viral infections with emphasis on COVID-19. Appl. Microbiol. Biotechnol. 2020, 104, 8089-8104. [CrossRef] [PubMed]

14. Miranda, J.M.; Anton, X.; Redondo-Valbuena, C.; Roca-Saavedra, P.; Rodriguez, J.A.; Lamas, A.; Franco, C.M.; Cepeda, A. Egg and egg-derived foods: Effects on human health and use as functional foods. Nutrients 2015, 7, 706-729. [CrossRef] [PubMed]

15. Díaz-Gutiérrez, L.; San Vicente, L.; Barrón, L.J.R.; Villarán, M.C.; Chávarri, M. Gamma-aminobutyric acid and probiotics: Multiple health benefits and their future in the global functional food and nutraceuticals market. J. Funct. Foods 2020, 64, 103669. [CrossRef]

16. Luo, Y.; Xiao, Y.; Zhao, J.; Zhang, H.; Chen, W.; Zhai, Q. The role of mucin and oligosaccharides via cross-feding activities by Bifidobacterium: A review. Int. J. Biol. Macromol. 2020. [CrossRef]

17. Alvarez-Vieites, E.; López-Santamarina, A.; Miranda, J.M.; Mondragón, A.d.C.; Lamas, A.; Cardelle-Cobas, A.; Nebot, C.; Franco, C.M.; Cepeda, A. Influence of the intestinal microbiota on diabetes management. Curr. Pharm. Biotechnol. 2020, 21, $1603-1615$. [CrossRef]

18. Roca-Saavedra, P.; Mendez-Vilabrille, V.; Miranda, J.M.; Nebot, C.; Cardelle-Cobas, A.; Franco, C.M.; Cepeda, A. Food additives, contaminants and other minor components: Effects on human gut microbiota-A review. J. Physiol. Biochem. 2018, $74,69-83$. [CrossRef]

19. Villena, J.; Vizoso-Pinto, M.G.; Kitazawa, H. Intestinal innate antiviral immunity and immunobiotics: Beneficial effects against rotavirus infection. Front. Immunol. 2016, 7, 563. [CrossRef]

20. Wan Mohd Kamaluddin, W.N.F.; Rismayuddin, N.A.R.; Ismail, A.F.; Mohamad Aidid, E.; Othman, N.; Mohamad, N.A.H.; Arzmi, M.H. Probiotic inhibits oral carcinogenesis: A systematic review and meta-analysis. Arch. Oral Biol. 2020, 118, 104855. [CrossRef]

21. Abdolalipour, E.; Mahooti, M.; Salehzadeh, A.; Torabi, A.; Mohebbi, S.R.; Gorji, A.; Ghaemi, A. Evaluation of the antitumor immune responses of probiotic Bifidobacterium bifidum in human papillomavirus-induced tumor model. Microb. Pathog. 2020, 145, 104207. [CrossRef]

22. Khani, S.; Motamedifar, M.; Golmoghaddam, H.; Hosseini, H.M.; Hashemizadeh, Z. In vitro study of the effect of a probiotic bacterium Lactobacillus rhamnosus against herpes simplex virus type 1. Braz. J. Infect. Dis. 2012, 16, 129-135. [PubMed]

23. Dhar, D.; Mohanty, A. Gut microbiota and Covid-19- possible link and implications. Virus Res. 2020, 285, 198018. [CrossRef] [PubMed]

24. Antushevich, H. Interplays between inflammasomes and viruses, bacteria (pathogenic and probiotic), yeasts and parasites. Immunol. Lett. 2020, 228, 1-14. [CrossRef] [PubMed]

25. Lehtoranta, L.; Pitkäranta, A.; Korpela, R. Probiotics in respiratory virus infections. Eur. J. Clin. Microbiol. Infect. Dis. 2014, 33, 1289-1302. [CrossRef] [PubMed] 
26. Ou, Y.C.; Fu, H.C.; Tseng, C.W.; Wu, C.H.; Tsai, C.C.; Lin, H. The influence of probiotics on genital high-risk human papilloma virus clearance and quality of cervical smear: A randomized placebo-controlled trial. BMC Women's Health 2019, $19,103$. [CrossRef]

27. Zolnikova, O.; Komkova, I.; Potskherashvili, N.; Trukhmanov, A.; Ivashkin, V. Application of probiotics for acute respiratory tract infections. Ital. J. Med. 2018, 12, 32-38. [CrossRef]

28. Yeo, J.-M.; Lee, H.-J.; Kim, J.-W.; Lee, J.-B.; Park, S.-Y.; Choi, I.-S.; Song, C.-S. Lactobacillus fermentum CJL-112 protects mice against influenza virus infection by activating T-helper 1 and eliciting a protective immune response. Int. Immunopharmacol. 2014, 18, 50-54. [CrossRef]

29. Woolhouse, M.; Scott, F.; Hudson, Z.; Howey, R.; Chase-Topping, M. Human viruses: Discovery and emergence. Philos. Trans. $R$ Soc. B Biol. Sci. 2012, 367, 2864-2871. [CrossRef]

30. Kutter, J.S.; Spronken, M.I.; Fraaij, P.L.; Fouchier, R.A.; Herfst, S. Transmission routes of respiratory viruses among humans. Curr. Opin. Virol. 2018, 28, 142-151. [CrossRef]

31. Berry, M.; Gamieldien, J.; Fielding, B.C. Identification of new respiratory viruses in the new millennium. Viruses 2015, 7, 996-1019. [CrossRef]

32. Karst, S.M. The influence of commensal bacteria on infection with enteric viruses. Nat. Rev. Microbiol. 2016, 14, 197-204 [CrossRef] [PubMed]

33. Sander, A.-L.; Corman, V.M.; Lukashev, A.N.; Drexler, J.F. Evolutionary Origins of Enteric Hepatitis Viruses. Cold Spring Harb. Perspect. Med. 2018, 8, a031690. [CrossRef] [PubMed]

34. Lemon, S.M.; Walker, C.M. Hepatitis A virus and hepatitis E virus: Emerging and re-emerging enterically transmitted hepatitis viruses. Cold Spring Harb. Perspect. Med. 2019, 9, a031823. [CrossRef] [PubMed]

35. Tahaei, S.M.E.; Mohebbi, S.R.; Zali, M.R. Enteric hepatitis viruses. Gastroenterol. Hepatol. Bed Bench 2012, 5, 7.

36. Bansal, R.; Tutrone, W.D.; Weinberg, J.M. Viral skin infections in the elderly: Diagnosis and management. Drugs Aging 2002, 19, 503-514. [CrossRef]

37. O'Dell, M.L. Skin and wound infections: An overview. Am. Fam. Physician 1998, 57, 2424-2432.

38. Nunes, E.M.; Talpe-Nunes, V.; Sichero, L. Epidemiology and biology of cutaneous human papillomavirus. Clinics 2018, 73, e489s. [CrossRef]

39. Handfield, C.; Kwock, J.; MacLeod, A.S. Innate Antiviral Immunity in the Skin. Trends Immunol. 2018, 39, 328-340. [CrossRef]

40. World Health Organization. WHO Expert Consultation on Rabies: Third Report; World Health Organization: Geneva, Switzerland, 2018; Available online: https:/ / apps.who.int/iris/bitstream/handle/10665/272364/9789241210218-eng.pdf?sequence=1\& isAllowed=y (accessed on 8 December 2020).

41. Abdulazeez, M.; Kia, G.S.N.; Abarshi, M.M.; Muhammad, A.; Ojedapo, C.E.; Atawodi, J.C.; Dantong, D.; Kwaga, J.K.P. Induction of Rabies virus infection in mice brain may up and down regulate type II interferon gamma via epigenetic modifications. Metab. Brain Dis. 2020, 35, 819-827. [CrossRef]

42. Beckham, J.D.; Tyler, K.L. Arbovirus infections. Continuum (Minneap. Minn.) 2015, 21, 1599. [CrossRef]

43. Gangoso, L.; Aragonés, D.; Martínez-de la Puente, J.; Lucientes, J.; Delacour-Estrella, S.; Estrada Peña, R.; Montalvo, T.; BuenoMarí, R.; Bravo-Barriga, D.; Frontera, E.; et al. Determinants of the current and future distribution of the West Nile virus mosquito vector Culex pipiens in Spain. Environ. Res. 2020, 188, 109837. [CrossRef] [PubMed]

44. Zakham, F.; Al-habal, M.; Taher, R.; Alaoui, A.; El Mzibri, M. Viral hemorrhagic fevers in the Tihamah region of the western Arabian Peninsula. PLoS Negl. Trop. Dis. 2017, 11, e0005322. [CrossRef] [PubMed]

45. Iannetta, M.; Di Caro, A.; Nicastri, E.; Vairo, F.; Masanja, H.; Kobinger, G.; Mirazimi, A.; Ntoumi, F.; Zumla, A.; Ippolito, G. Viral hemorrhagic fevers other than Ebola and Lassa. Infect. Dis. Clin. N. Am. 2019, 33, 977-1002. [CrossRef]

46. Looft, T.; Allen, H.K. Collateral effects of antibiotics on mammalian gut microbiomes. Gut Microbes 2012, 3, 463-467. [CrossRef] [PubMed]

47. Dermyshi, E.; Wang, Y.; Yan, C.; Hong, W.; Qiu, G.; Gong, X.; Zhang, T. The "golden Age" of Probiotics: A systematic review and meta-analysis of randomized and observational studies in preterm infants. Neonatology 2017, 112, 9-23. [CrossRef] [PubMed]

48. Baud, D.; Agri, V.D.; Gibson, G.R.; Reid, G.; Giannoni, E. Using probiotics to flatten the curve of coronavirus disease COVID-2019 pandemic. Front. Public Health 2020, 8, 186. [CrossRef] [PubMed]

49. Kikuchi, Y.; Kunitoh-Asari, A.; Hayakawa, K.; Imai, S.; Kasuya, K.; Abe, K.; Adachi, Y.; Fukudome, S.I.; Takahashi, Y.; Hachimura, S. Oral administration of Lactobacillus plantarum strain AYA enhances IgA secretion and provides survival protection against influenza virus infection in mice. PLoS ONE 2014, 9, e86416. [CrossRef]

50. Kawase, M.; He, F.; Kubota, A.; Harata, G.; Hiramatsu, M. Oral administration of lactobacilli from human intestinal tract protects mice against influenza virus infection. Lett. Appl. Microbiol. 2010, 51, 6-10. [CrossRef]

51. Park, M.K.; Ngo, V.; Kwon, Y.M.; Lee, Y.Y.; Yoo, S.; Cho, Y.H.; Hong, S.M.; Hwang, H.S.; Ko, E.J.; Jung, Y.J.; et al. Lactobacillus plantarum DK119 as a probiotic confers protection against Influenza virus by modulating innate immunity. PLoS ONE 2013, 8, e75368. [CrossRef]

52. Takeda, S.; Takeshita, M.; Kikuchi, Y.; Dashnyam, B.; Kawahara, S.; Yoshida, H.; Watanabe, W.; Muguruma, M.; Kurokawa, M. Efficacy of oral administration of heat-killed probiotics from Mongolian dairy products against influenza infection in mice: Alleviation of influenza infection by its immunomodulatory activity through intestinal immunity. Int. Immunopharmacol. 2011, 11, 1976-1983. [CrossRef] 
53. Song, J.A.; Kim, H.J.; Hong, S.K.; Lee, D.H.; Lee, S.W.; Song, C.S.; Kim, K.T.; Choi, I.S.; Lee, J.B.; Park, S.Y. Oral intake of Lactobacillus rhamnosus M21 enhances the survival rate of mice lethally infected with influenza virus. J. Microbiol. Immunol. Infect. 2016, 49, 16-23. [CrossRef] [PubMed]

54. Belkacem, N.; Serafini, N.; Wheeler, R.; Derrien, M.; Boucinha, L.; Couesnon, A.; Cerf-Bensussan, N.; Boneca, I.G.; Di Santo, J.P.; Taha, M.-K.; et al. Lactobacillus paracasei feeding improves immune control of influenza infection in mice. PLoS ONE 2017, 12, e0184976. [CrossRef] [PubMed]

55. Lee, Y.N.; Youn, H.N.; Kwon, J.H.; Lee, D.H.; Park, J.K.; Yuk, S.S.; Erdene-Ochir, T.O.; Kim, K.T.; Lee, J.B.; Park, S.Y.; et al. Sublingual administration of Lactobacillus rhamnosus affects respiratory immune responses and facilitates protection against influenza virus infection in mice. Antivir. Res. 2013, 98, 284-290. [CrossRef] [PubMed]

56. Harata, G.; He, F.; Hiruta, N.; Kawase, M.; Kubota, A.; Hiramatsu, M.; Yausi, H. Intranasal administration of Lactobacillus rhamnosus GG protects mice from H1N1 influenza virus infection by regulating respiratory immune responses. Lett. Appl. Microbiol. 2010, 50, 597-602. [CrossRef] [PubMed]

57. Kobayashi, N.; Saito, T.; Uematsu, T.; Kishi, K.; Toba, M.; Kohda, N.; Suzuki, T. Oral administration of heat-killed Lactobacillus pentosus strain b240 augments protection against influenza virus infection in mice. Int. Immunopharmacol. 2011, 11, 199-203. [CrossRef] [PubMed]

58. Zelaya, H.; Tada, A.; Vizoso-Pinto, M.G.; Salva, S.; Kanmani, P.; Agüero, G.; Alvarez, S.; Kitazawa, H.; Villena, J. Nasal priming with immunobiotic Lactobacillus rhamnosus modulates inflammation-coagulation interactions and reduces influenza virus-associated pulmonary damage. Inflamm. Res. 2015, 64, 589-602. [CrossRef]

59. Izumo, T.; Maekawa, T.; Ida, M.; Noguchi, A.; Kitagawa, Y.; Shibata, H.; Yasui, H.; Kiso, Y. Effect of intranasal administration of Lactobacillus pentosus S-PT84 on influenza virus infection in mice. Int. Immunopharmacol. 2010, 10, 1101-1106. [CrossRef]

60. Kawahara, T.; Takahashi, T.; Oishi, K.; Tanaka, H.; Masuda, M.; Takahashi, S.; Takano, M.; Kawakami, T.; Fukushima, K.; Kanazawa, H.; et al. Consecutive oral administration of Bifidobacterium longum MM-2 improves the defense system against influenza virus infection by enhancing natural killer cell activity in a murine model. Microbiol. Immunol. 2015, 59, 1-12. [CrossRef]

61. Waki, N.; Yajima, N.; Suganuma, H.; Buddle, B.M.; Luo, D.; Heiser, A.; Zheng, T. Oral administration of Lactobacillus brevis KB290 to mice alleviates clinical symptoms following influenza virus infection. Lett. Appl. Microbiol. 2014, 58, 87-93. [CrossRef]

62. Nakayama, Y.; Moriya, T.; Sakai, F.; Ikeda, N.; Shiozaki, T.; Hosoya, T.; Nakagawa, H.; Miyazaki, T. Oral administration of Lactobacillus gasseri SBT2055 is effective for preventing influenza in mice. Sci. Rep. 2014, 4, 4638. [CrossRef]

63. Kiso, M.; Takano, R.; Sakabe, S.; Katsura, H.; Shinya, K.; Uraki, R.; Watanabe, S.; Saito, H.; Toba, M.; Kohda, N.; et al. Protective efficacy of orally administered, heat-killed Lactobacillus pentosus b240 against influenza A virus. Sci. Rep. 2013, 3, 1563. [CrossRef] [PubMed]

64. Kumpu, M.; Kekkonen, R.A.; Kautiainen, H.; Järvenpää, S.; Kristo, A.; Huovinen, P.; Pitkäranta, A.; Korpela, R.; Hatakka, K. Milk containing probiotic Lactobacillus rhamnosus GG and respiratory illness in children: A randomized, double-blind, placebo-controlled trial. Eur. J. Clin. Nutr. 2012, 66, 1020-1023. [CrossRef] [PubMed]

65. Garaiova, I.; Muchová, J.; Nagyová, Z.; Wang, D.; Li, J.V.; Országhová, Z.; Michael, D.R.; Plummer, S.F.; Ďuračková, Z. Probiotics and vitamin $C$ for the prevention of respiratory tract infections in children attending preschool: A randomised controlled pilot study. Eur. J. Clin. Nutr. 2015, 69, 373-379. [CrossRef]

66. Luoto, R.; Ruuskanen, O.; Waris, M.; Kalliomäki, M.; Salminen, S.; Isolauri, E. Prebiotic and probiotic supplementation prevents rhinovirus infections in preterm infants: A randomized, placebo-controlled trial. J. Allergy Clin. Immunol. 2014, 133, 405-413. [CrossRef] [PubMed]

67. Lehtoranta, L.; Söderlund-Venermo, M.; Nokso-Koivisto, J.; Toivola, H.; Blomgren, K.; Hatakka, K.; Poussa, T.; Korpela, R.; Pitkäranta, A. Human bocavirus in the nasopharynx of otitis-prone children. Int. J. Pediatric Otorhinolaryngol. 2012, 76, 206-211. [CrossRef] [PubMed]

68. Hojsak, I.; Močić Pavić, A.; Kos, T.; Dumančić, J.; Kolaček, S. Bifidobacterium animalis subsp. lactis in prevention of common infections in healthy children attending day care centers-Randomized, double blind, placebo-controlled study. Clin. Nutr. 2016, 35, 587-591. [CrossRef]

69. Hu, X.; Zhang, H.; Lu, H.; Qian, G.; Lv, L.; Zhang, C.; Guo, J.; Jiang, H.; Zheng, B.; Yang, F.; et al. The effect of probiotic treatment on patients infected with the H7N9 influenza virus. PLoS ONE 2016, 11, e0151976. [CrossRef]

70. Berggren, A.; Lazou Ahrén, I.; Larsson, N.; Önning, G. Randomised, double-blind and placebo-controlled study using new probiotic lactobacilli for strengthening the body immune defence against viral infections. Eur. J. Nutr. 2011, 50, 203-210. [CrossRef]

71. Pu, F.; Guo, Y.; Li, M.; Zhu, H.; Wang, S.; Shen, X.; He, M.; Huang, C.; He, F. Yogurt supplemented with probiotics can protect the healthy elderly from respiratory infections: A randomized controlled open-label trial. Clin. Interv. Aging 2017, 12, $1223-1231$. [CrossRef]

72. Zhang, H.; Yeh, C.; Jin, Z.; Ding, L.; Liu, B.Y.; Zhang, L.; Dannelly, H.K. Prospective study of probiotic supplementation results in immune stimulation and improvement of upper respiratory infection rate. Synth. Syst. Biotechnol. 2018, 3, 113-120. [CrossRef]

73. Guillemard, E.; Tondu, F.; Lacoin, F.; Schrezenmeir, J. Consumption of a fermented dairy product containing the probiotic Lactobacillus casei DN-114 001 reduces the duration of respiratory infections in the elderly in a randomised controlled trial. Br. J. Nutr. 2010, 103, 58-68. [CrossRef] 
74. Chong, H.X.; Yusoff, N.A.A.; Hor, Y.Y.; Lew, L.C.; Jaafar, M.H.; Choi, S.B.; Yusoff, M.S.B.; Wahid, N.; Abdullah, M.F.I.L.; Zakaria, N.; et al. Lactobacillus plantarum DR7 improved upper respiratory tract infections via enhancing immune and inflammatory parameters: A randomized, double-blind, placebo-controlled study. J. Dairy Sci. 2019, 102, 4783-4797. [CrossRef]

75. Davidson, L.E.; Fiorino, A.M.; Snydman, D.R.; Hibberd, P.L. Lactobacillus GG as an immune adjuvant for live-attenuated influenza vaccine in healthy adults: A randomized double-blind placebo-controlled trial. Eur. J. Clin. Nutr. 2011, 65, 501-507. [CrossRef]

76. Olivares, M.; Díaz-Ropero, M.P.; Sierra, S.; Lara-Villoslada, F.; Fonollá, J.; Navas, M.; Rodríguez, J.M.; Xaus, J. Oral intake of Lactobacillus fermentum CECT5716 enhances the effects of influenza vaccination. Nutrition 2007, 23, 254-260. [CrossRef]

77. Rizzardini, G.; Eskesen, D.; Calder, P.C.; Capetti, A.; Jespersen, L.; Clerici, M. Evaluation of the immune benefits of two probiotic strains Bifidobacterium animalis ssp. lactis, BB- $12^{\circledR}$ and Lactobacillus paracasei ssp. paracasei, L. casei $431^{\circledR}$ in an influenza vaccination model: A randomised, double-blind, placebo-controlled study. Br. J. Nutr. 2012, 107, 876-884. [CrossRef]

78. Yamamoto, Y.; Saruta, J.; Takahashi, T.; To, M.; Shimizu, T.; Hayashi, T.; Morozumi, T.; Kubota, N.; Kamata, Y.; Makino, S.; et al. Effect of ingesting yogurt fermented with Lactobacillus delbrueckii ssp. bulgaricus OLL1073R-1 on influenza virus-bound salivary IgA in elderly residents of nursing homes: A randomized controlled trial. Acta Odontol. Scand. 2019, 77, 517-524. [CrossRef]

79. Boge, T.; Rémigy, M.; Vaudaine, S.; Tanguy, J.; Bourdet-Sicard, R.; van der Werf, S. A probiotic fermented dairy drink improves antibody response to influenza vaccination in the elderly in two randomised controlled trials. Vaccine 2009, 27, 5677-5684. [CrossRef]

80. Kawahara, T.; Makizaki, Y.; Oikawa, Y.; Tanaka, Y.; Maeda, A.; Shimakawa, M.; Komoto, S.; Moriguchi, K.; Ohno, H.; Taniguchi, K. Oral administration of Bifidobacterium bifidum G9-1 alleviates rotavirus gastroenteritis through regulation of intestinal homeostasis by inducing mucosal protective factors. PLoS ONE 2017, 12, e0173979. [CrossRef]

81. Guillemard, E.; Tanguy, J.; Flavigny, A.L.; De la Motte, S.; Schrezenmeir, J. Effects of consumption of a fermented dairy product containing the probiotic Lactobacillus casei DN-114 001 on common respiratory and gastrointestinal infections in shift workers in a randomized controlled trial. J. Am. Coll. Nutr. 2010, 29, 455-468. [CrossRef]

82. Kumpu, M.; Lehtoranta, L.; Roivainen, M.; Rönkkö, E.; Ziegler, T.; Söderlund-Venermo, M.; Kautiainen, H.; Järvenpää, S.; Kekkonen, R.; Hatakka, K.; et al. The use of the probiotic Lactobacillus rhamnosus GG and viral findings in the nasopharynx of children attending day care. J. Med. Virol. 2013, 85, 1632-1638. [CrossRef]

83. Lake, M.A. What we know so far: COVID-19 current clinical knowledge and research. Clin. Med. 2020, 20, 124. [CrossRef]

84. Xu, Y.; Li, X.; Zhu, B.; Liang, H.; Fang, C.; Gong, Y.; Guo, Q.; Sun, X.; Zhao, D.; Shen, J. Characteristics of pediatric SARS-CoV-2 infection and potential evidence for persistent fecal viral shedding. Nat. Med. 2020, 26, 502-505. [CrossRef]

85. Albarracin, L.; Kobayashi, H.; Iida, H.; Sato, N.; Nochi, T.; Aso, H.; Salva, S.; Alvarez, S.; Kitazawa, H.; Villena, J. Transcriptomic analysis of the innate antiviral immune response in porcine intestinal epithelial cells: Influence of immunobiotic lactobacilli. Front. Immunol. 2017, 8, 57. [CrossRef]

86. Vitetta, L.; Vitetta, G.; Hall, S. Immunological tolerance and function: Associations between intestinal bacteria, probiotics, prebiotics, and phages. Front. Immunol. 2018, 9, 2240. [CrossRef]

87. Chiba, E.; Villena, J.; Hosoya, S.; Takanashi, N.; Shimazu, T.; Aso, H.; Tohno, M.; Suda, Y.; Kawai, Y.; Saito, T.; et al. A newly established bovine intestinal epithelial cell line is effective for in vitro screening of potential antiviral immunobiotic microorganisms for cattle. Res. Vet. Sci. 2012, 93, 688-694. [CrossRef]

88. Kumar, R.K.V.; Seo, B.J.; Mun, M.R.; Kim, C.-J.; Lee, I.; Kim, H.; Park, Y.-H. Putative probiotic Lactobacillus spp. from porcine gastrointestinal tract inhibit transmissible gastroenteritis coronavirus and enteric bacterial pathogens. Trop. Anim. Health Prod. 2010, 42, 1855-1860.

89. Preidis, G.A.; Saulnier, D.M.; Blutt, S.E.; Mistretta, T.A.; Riehle, K.P.; Major, A.M.; Venable, S.F.; Barrish, J.P.; Finegold, M.J.; Petrosino, J.F.; et al. Host response to probiotics determined by nutritional status of rotavirus-infected neonatal mice. J. Pediatr. Gastroenterol. Nutr. 2012, 55, 299-307. [CrossRef]

90. Hoang, P.M.; Cho, S.; Kim, K.E.; Byun, S.J.; Lee, T.K.; Lee, S. Development of Lactobacillus paracasei harboring nucleic acidhydrolyzing 3D8 scFv as a preventive probiotic against murine norovirus infection. Appl. Microbiol. Biotechnol. 2015, 99, $2793-2803$. [CrossRef]

91. Freedman, S.B.; Xie, J.; Nettel-Aguirre, A.; Pang, X.-L.; Chui, L.; Williamson-Urquhart, S.; Schnadower, D.; Schuh, S.; Sherman, P.M.; Lee, B.E.; et al. A randomized trial evaluating virus-specific effects of a combination probiotic in children with acute gastroenteritis. Nat. Commun. 2020, 11, 2533. [CrossRef]

92. Majamaa, H.; Isolauri, E.; Saxelin, M.; Vesikari, T. Lactic acid bacteria in the treatment of acute rotavirus gastroenteritis. J. Pediatr. Gastroenterol. Nutr. 1995, 20, 333-383. [CrossRef]

93. Brun, P.; Scarpa, M.; Marchiori, C.; Sarasin, G.; Caputi, V.; Porzionato, A.; Giron, M.C.; Palù, G.; Castagliuolo, I. Saccharomyces boulardii CNCM I-745 supplementation reduces gastrointestinal dysfunction in an animal model of IBS. PLoS ONE 2017, 12, $\mathrm{e} 0181863$.

94. Oo, K.M.; Ayelwin, A.; Kyaw, Y.Y.; Tun, W.M.; Fukada, K.; Goshima, A.; Shimada, T.; Okada, S. Safety and long-term effect of the probiotic FK-23 in patients with hepatitis C virus infection. Biosci. Microbiota Food Health 2016, 35, 2015-2024. [CrossRef] [PubMed]

95. Palma, E.; Recine, N.; Domenici, L.; Giorgini, M.; Pierangeli, A.; Panici, P.B. Long-term Lactobacillus rhamnosus BMX 54 application to restore a balanced vaginal ecosystem: A promising solution against HPV-infection. BMC Infect. Dis. 2018, 18, 13. [CrossRef] 
96. Verhoeven, V.; Renard, N.; Makar, A.; Royen, P.V.; Bogers, J.P.; Lardon, F.; Peeters, M.; Baay, M. Probiotics enhance the clearance of human papillomavirus-related cervical lesions: A prospective controlled pilot study. Eur. J. Cancer Prev. 2013, $22,46-51$. [CrossRef] [PubMed]

97. Scheri, G.C.; Fard, S.N.; Schietroma, I.; Mastrangelo, A.; Pinacchio, C.; Giustini, N.; Serafino, S.; De Girolamo, G.; Cavallari, E.N.; Statzu, M.; et al. Modulation of tryptophan/serotonin pathway by probiotic supplementation in human immunodeficiency virus-positive patients: Preliminary results of a new study approach. Int. J. Trytophan Res. 2017, 10, 1178646917710668.

98. Hummelen, R.; Changalucha, J.; Butamanya, N.L.; Cook, A.; Habbema, J.D.F.; Reid, G. Lactobacillus rhamnosus GR-1 and L. reuteri RC-14 to prevent or cure bacterial vaginosis among women with HIV. Int. J. Gynecol. Obstet. 2010, 111, 245-248. [CrossRef]

99. Cunningham-Rundles, S.; Ahrné, S.; Johann-Liang, R.; Abuav, R.; Dunn-Navarra, A.M.; Grassey, C.; Bengmark, S.; Cervia, J.S. Effect of probiotic bacteria on microbial host defense, growth and immune function in human immunodeficiency virus type-1 infection. Nutrients 2011, 3, 1042-1070. [CrossRef]

100. Wolf, B.W.; Wheeler, K.B.; Ataya, D.G.; Garleb, K.A. Safety and tolerance of Lactobacillus reuteri supplementation to a population infected with the human immunodeficiency virus. Food Chem. Toxicol. 1998, 36, 1085-1094. [CrossRef]

101. D'Angelo, C.; Reale, M.; Costantini, E. Microbiota and probiotics in health and HIV infection. Nutrients 2017, 6, 615. [CrossRef]

102. Reikvan, D.H.; Meyer-Myklestad, M.H.; Trøseid, M.; Stiksrud, B. Probiotics to manage inflammation in HIV infection. Curr. Opin. Infect. Dis. 2020, 33, 34-43. [CrossRef]

103. Haghighat, L.; Crum-Cianflone, N.F. The potential risks of probiotics among HIV-infected persons: Bacteraemia due to Lactobacillus acidophilus and review of the literature. Int. J. STD AIDS 2016, 27, 1223-1230. [CrossRef]

104. Luong, M.L.; Sareyyupoglu, B.; Nguyen, M.H.; Silveira, F.P.; Shields, R.K.; Potoski, B.A.; Pasculle, W.A.; Clancy, C.J.; Toyoda, Y. Lactobacillus probiotic use in cardiothoracic transplant recipients: A link to invasive Lactobacillus infection? Transpl. Infect. Dis. 2010, 12, 561-564. [CrossRef]

105. Li, Y.; Yu, T.; Yan, H.; Li, D.; Yu, T.; Yuan, T.; Rahaman, A.; Ali, S.; Abbas, F.; Dian, Z.; et al. Vaginal microbiota and HPV infection: Novel mechanistic insights and therapeutic strategies. Infect. Drug Resist. 2020, 13, 1213-1220. [CrossRef]

106. Gori, A.; Tincati, C.; Rizzardini, G.; Torti, C.; Quirino, T.; Haarman, M.; Amor, K.B.; Van Schaik, J.; Vriesema, A.; Knol, J.; et al. Early impairment of gut function and gut flora supporting a role for alteration of gastrointestinal mucosa in human immunodeficiency virus pathogenesis. J. Clin. Microbiol. 2008, 46, 757-758. [CrossRef] 